\title{
Geology and Assessment of Undiscovered Oil and Gas Resources of the Eurasia Basin Province, 2008
}

Chapter DD of

The 2008 Circum-Arctic Resource Appraisal

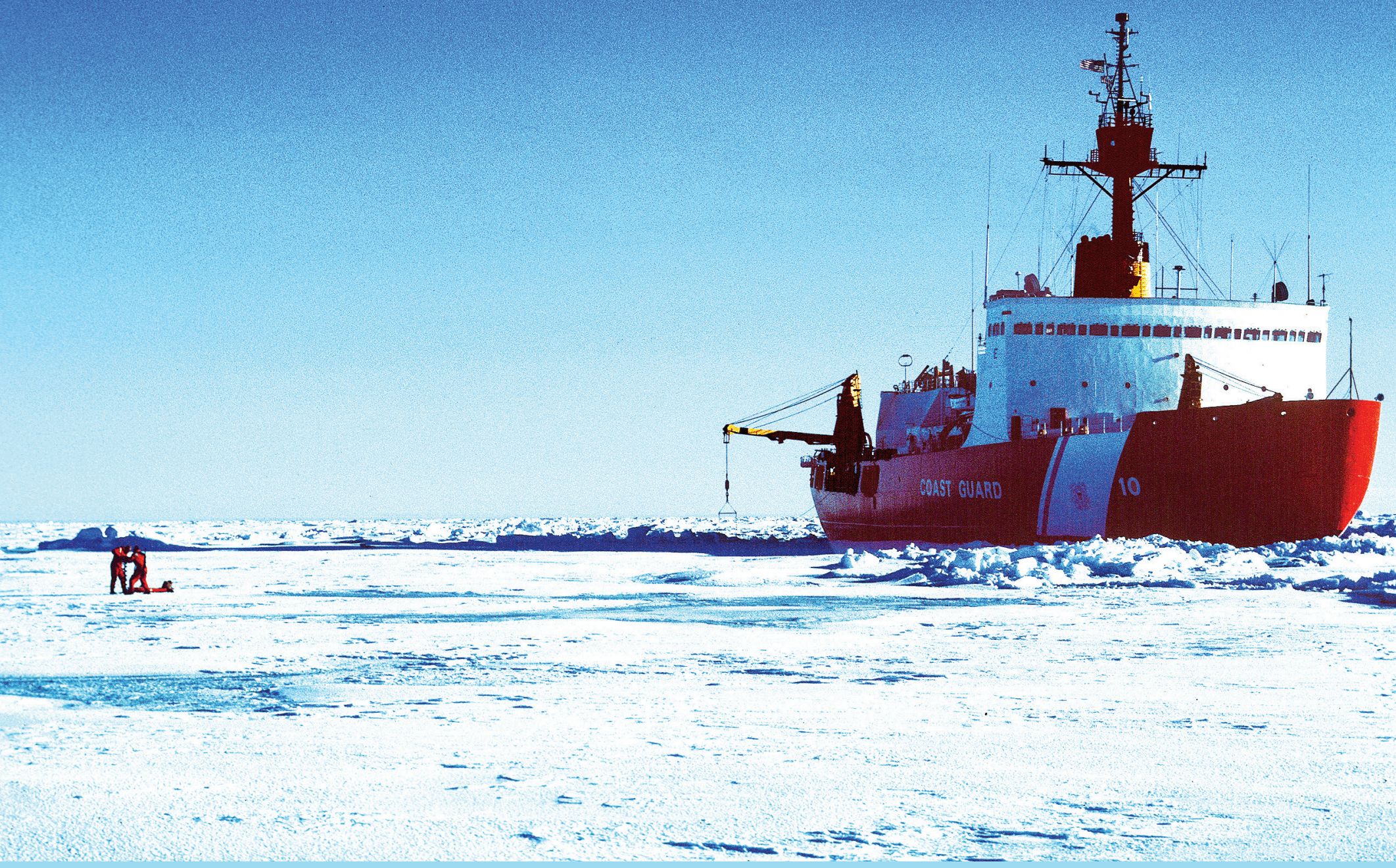

Professional Paper 1824

U.S. Department of the Interior

U.S. Geological Survey 
COVER

Two scientists from the U.S. Geological Survey core through the sea ice in the Canada Basin of the Arctic Ocean during a research cruise aboard the U.S. Coast Guard icebreaker Polar Star. Photograph by Thomas E. Moore. 


\section{Geology and Assessment of Undiscovered Oil and Gas Resources of the Eurasia Basin Province, 2008}

By Thomas E. Moore and Janet K. Pitman

Chapter DD of

The 2008 Circum-Arctic Resource Appraisal

Edited by T.E. Moore and D.L. Gautier

Professional Paper 1824 


\title{
U.S. Department of the Interior DAVID BERNHARDT, Secretary
}

\author{
U.S. Geological Survey \\ James F. Reilly II, Director
}

U.S. Geological Survey, Reston, Virginia: 2019

For more information on the USGS - the Federal source for science about the Earth, its natural and living resources, natural hazards, and the environment-visit https://www.usgs.gov or call 1-888-ASK-USGS.

For an overview of USGS information products, including maps, imagery, and publications, visit https://store.usgs.gov.

Any use of trade, firm, or product names is for descriptive purposes only and does not imply endorsement by the U.S. Government.

Although this information product, for the most part, is in the public domain, it also may contain copyrighted materials as noted in the text. Permission to reproduce copyrighted items must be secured from the copyright owner.

Suggested citation:

Moore, T.E. and Pitman, J.K., 2019, Geology and assessment of undiscovered oil and gas resources of the Eurasia Basin Province, 2008, chap. DD of Moore, T.E., and Gautier, D.L., eds., The 2008 Circum-Arctic Resource Appraisal: U.S. Geological Survey Professional Paper 1824, 35 p., https://doi.org/10.3133/pp1824DD.

ISSN 2330-7102 (online) 


\section{The 2008 Circum-Arctic Resource Appraisal}

\section{Chapters}

A. Introduction to the 2008 Circum-Arctic Resource Appraisal (CARA) Professional Paper By Donald L. Gautier and Thomas E. Moore

B. Methodology for Assessment of Undiscovered Oil and Gas Resources for the 2008 Circum-Arctic Resource Appraisal

By Ronald R. Charpentier

\section{North America}

C. Geology and Assessment of Undiscovered Oil and Gas Resources of the Chukchi Borderland Province, 2008

By Kenneth J. Bird and David W. Houseknecht

D. Geology and Assessment of Undiscovered Oil and Gas Resources of the Hope Basin

Province, 2008

By Kenneth J. Bird, David W. Houseknecht, and Janet K. Pitman

E. Geology and Assessment of Undiscovered Oil and Gas Resources of the Arctic Alaska Petroleum Province, 2008

By David W. Houseknecht, Kenneth J. Bird, and Christopher P. Garrity

F. Geology and Assessment of Undiscovered Oil and Gas Resources of the Yukon Flats Basin Province, 2008

By Kenneth J. Bird and Richard G. Stanley

G. Geology and Assessment of Undiscovered Oil and Gas Resources of the Northwest Canada Interior Basins Province, Arctic Canada, 2008

By Marilyn E. Tennyson and Janet K. Pitman

H. Geology and Assessment of Undiscovered Oil and Gas Resources of the Franklinian Shelf Province, Arctic Canada and North Greenland, 2008

By Marilyn E. Tennyson and Janet K. Pitman

I. Geology and Assessment of Undiscovered Oil and Gas Resources of the Sverdrup Basin Province, Arctic Canada, 2008

By Marilyn E. Tennyson and Janet K. Pitman 


\section{Greenland}

J. Geology and Assessment of Undiscovered Oil and Gas Resources of the West GreenlandEast Canada Province, 2008

By Christopher J. Schenk

K. Geology and Assessment of Undiscovered Oil and Gas Resources of the East Greenland Rift Basins Province, 2008

By Donald L. Gautier

\section{North Atlantic Ocean}

L. Geology and Assessment of Undiscovered Oil and Gas Resources of the Jan Mayen Microcontinent Province, 2008

By Thomas E. Moore and Janet K. Pitman

\section{Eurasia}

M. Geology and Assessment of Undiscovered Oil and Gas Resources of the Mezen' Basin Province, 2008

By Timothy R. Klett and Janet K. Pitman

N. Geology and Assessment of Undiscovered Oil and Gas Resources of the Timan-Pechora Basin Province, Russia, 2008

By Christopher J. Schenk

0. Geology and Assessment of Undiscovered Oil and Gas Resources of the East Barents Basins Province and the Novaya Zemlya Basins and Admiralty Arch Province

By Timothy R. Klett

P. Geology and Assessment of Undiscovered Oil and Gas Resources of the North Kara Basins and Platforms Province, 2008

By Timothy R. Klett and Janet K. Pitman

0. Geology and Assessment of Undiscovered Oil and Gas Resources of the Northern West Siberian Mesozoic Composite Total Petroleum System of the West Siberian Basin Province, Russia, 2008

By Christopher J. Schenk

R. Geology and Assessment of Undiscovered Oil and Gas Resources of the Yenisey-Khatanga Basin Province, 2008

By Timothy R. Klett and Janet K. Pitman

S. Geology and Assessment of Undiscovered Oil and Gas Resources of the Northwest Laptev Sea Shelf Province, 2008

By Timothy R. Klett and Janet K. Pitman 
T. Geology and Assessment of Undiscovered Oil and Gas Resources of the Lena-Anabar Basin Province, 2008

By Timothy R. Klett and Janet K. Pitman

U. Geology and Assessment of Undiscovered Oil and Gas Resources of the Tunguska Basin Province, 2008

By Craig J. Wandrey and Timothy R. Klett

V. Geology and Assessment of Undiscovered Oil and Gas Resources of the Lena-Vilyui Basin Province, 2008

By Timothy R. Klett and Janet K. Pitman

W. Geology and Assessment of Undiscovered Oil and Gas Resources of the Laptev Sea Shelf Province, 2008

By Timothy R. Klett and Janet K. Pitman

X. Geology and Assessment of Undiscovered Oil and Gas Resources of the Zyryanka Basin Province, 2008

By Timothy R. Klett and Janet K. Pitman

Y. Geology and Assessment of Undiscovered Oil and Gas Resources of the East Siberian Sea Basin Province, 2008

By Kenneth J. Bird, David W. Houseknecht, and Janet K. Pitman

Z. Geology and Assessment of Undiscovered Oil and Gas Resources of the Vilkitskii Basin

Province, 2008

By Kenneth J. Bird, David W. Houseknecht, and Janet K. Pitman

AA. Geology and Assessment of Undiscovered Oil and Gas Resources of the Long Strait Province, 2008

By Kenneth J. Bird, David W. Houseknecht, and Janet K. Pitman

\section{Arctic Ocean}

BB. Geology and Assessment of Undiscovered Oil and Gas Resources of the Amerasia Basin Petroleum Province, 2008

By David W. Houseknecht, Kenneth J. Bird, and Christopher P. Garrity

CC. Geology and Assessment of Undiscovered Oil and Gas Resources of the LomonosovMakarov Province, 2008

By Thomas E. Moore, Kenneth J. Bird, and Janet K. Pitman

DD. Geology and Assessment of Undiscovered Oil and Gas Resources of the Eurasia Basin Province, 2008

By Thomas E. Moore and Janet K. Pitman 


\section{Contents}

Abstract

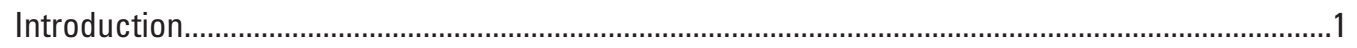

Eurasia Basin Province Description .........................................................................................

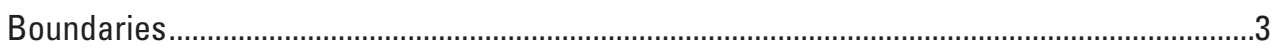

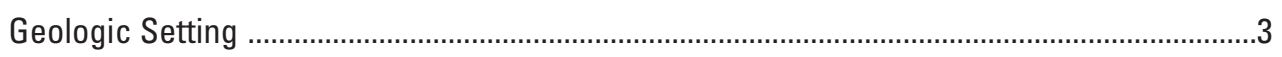

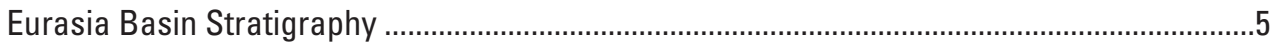

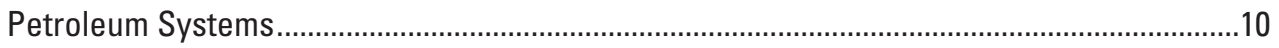

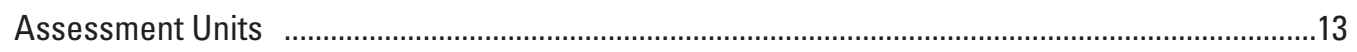

Lena Prodelta Assessment Unit ............................................................................................

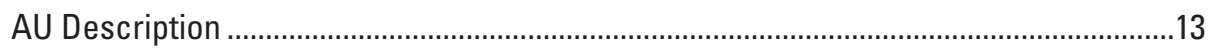

Geologic Model for Assessment ...........................................................................13

Geological Analysis of Assessment Unit Probability ....................................................13

Quantitative Assessment of Lena Prodelta Assesment Unit...........................................18

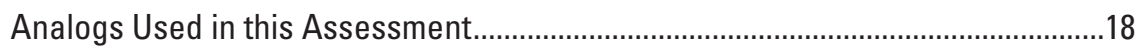

Numbers of Undiscovered Oil and Gas Accumulations ..........................................18

Sizes of Undiscovered Oil and Gas Accumulations ................................................19

Coproduct Ratios and Ancillary Data ..................................................................19

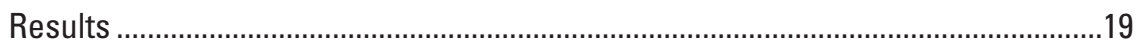

Nansen Basin Margin Assessment Unit.......................................................................19

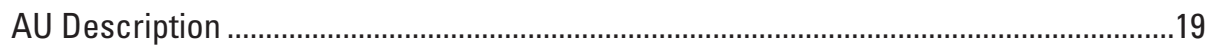

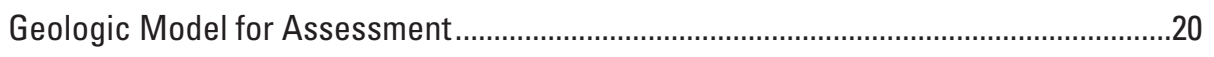

Geological Analysis of Assessment Unit Probability ..................................................20

Quantitative Assessment of Nansen Basin Margin Assesment Unit...............................23

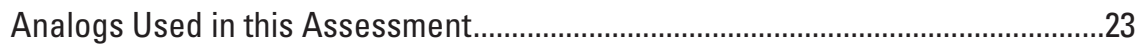

Numbers of Undiscovered Oil and Gas Accumulations ..........................................23

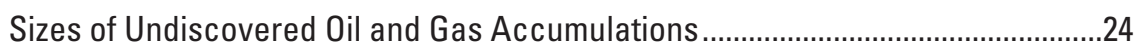

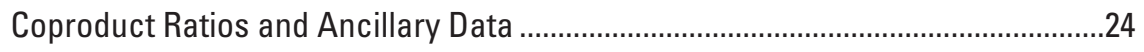

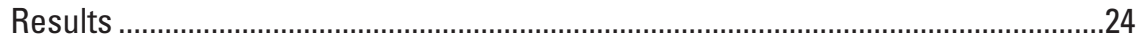

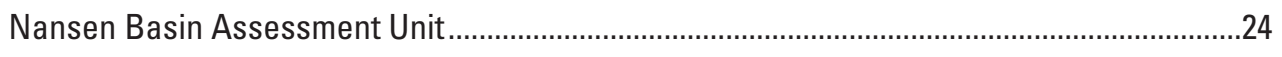

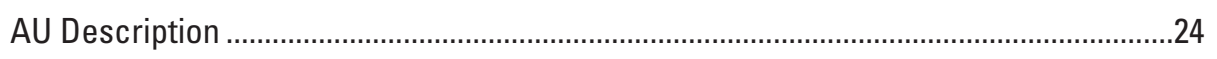

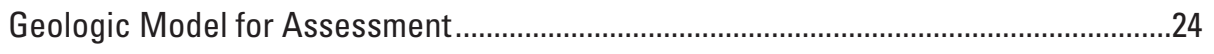

Geological Analysis of Assessment Unit Probability ..................................................24

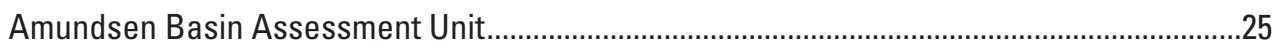

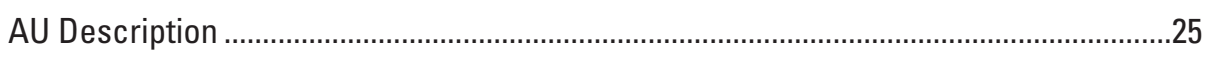

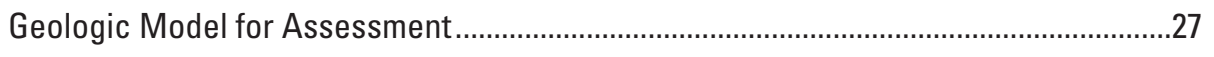

Geological Analysis of Assessment Unit Probability ..................................................27

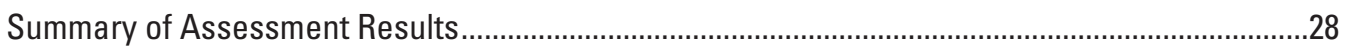

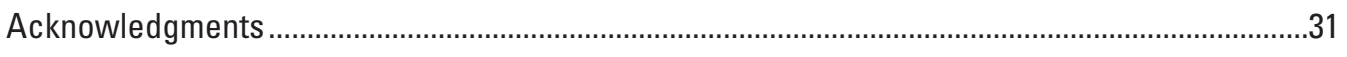

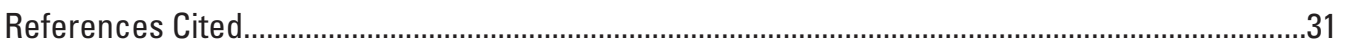




\section{Appendixes}

[Available for download at https://doi.org/10.3133/pp1824DD]

1. Input data for the Lena Prodelta Assessment Unit

2. Input data for the Nansen Basin Margin Assessment Unit

3. Input data for the Nansen Basin Assessment Unit

4. Input data for the Amundsen Basin Assessment Unit

\section{Figures}

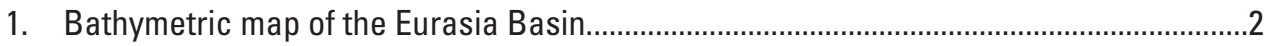

2. Map showing major structural features of the Eurasia Basin and nearby areas .............4

3. Seismic data and interpretation of Nansen Basin Margin and Nansen Basin

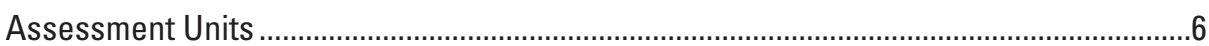

4. Seismic data and interpretations of Amundsen Basin Assessment Unit .........................7

5. Seismic interpretation of strike line MAGE-90704 in Lena Prodelta Assessment Unit. Diagram modified from Drachev and others (2003)

6. Stratigraphy at site of Arctic Coring Expedition (ACEX) and seismic stratigraphic models for Lomonosov Ridge and various parts of Eurasia Basin.

7. Approximate distribution of source rock strata in vicinity of Eurasia Basin ...................11

8. Burial history model for pseudowell LP1, located in a deep depocenter in Amundsen Basin in Lena Prodelta Assessment Unit AU ...................................................................14

9. Burial history model for pseudowell LP1, located in a deep depocenter in Amundsen Basin in Lena Prodelta Assessment Unit (AU) ..............................................................16

10. Burial history model for pseudowell LP2, located in central rift area of Gakkel Ridge in Lena Prodelta Assessment Unit (AU)

11. Burial history model for pseudowell NBM in Nansen Basin Margin Assessment Unit (AU).

12. Burial history model for pseudowell NB in Nansen Basin Assessment Unit (AU) ..........26

13. Burial history model for pseudowell $A B$ in Amundsen Basin Assessment Unit (AU) .....29

\section{Table}

1. Assessment results for the Eurasia Basin Province (conventional undiscovered resources). 



\title{
Chapter DD
}

\section{Geology and Assessment of Undiscovered Oil and Gas Resources of the Eurasia Basin Province}

\author{
By Thomas E. Moore and Janet K. Pitman
}

\section{Abstract}

The Eurasia Basin Petroleum Province comprises the younger, eastern half of the Arctic Ocean, including the Eurasia Basin and the outboard part of the continental margin of northern Europe in the Barents and Kara Seas. The province includes the slope and rise sedimentary prism of the Lena Delta, the north-facing outer shelf, slope, and rise of the European passive margin, and sedimentary accumulations in the deep Nansen and Amundsen Basins. The entire province lies north of the Arctic Circle beneath the polar ice cap and includes the North Pole.

The province is divided into four assessment units (AUs). The Lena Prodelta AU in the eastern part of the province consists of the deep-marine part of the Lena Delta, which has been deposited across the Gakkel Ridge, an ultraslow spreading ridge. The Nansen Basin Margin AU in the southern part of the province comprises the Cenozoic passive margin sequence of the rift margin of the western (European) part of the Eurasian plate. This AU spans the continent-ocean boundary and includes prerift strata along the outer continental margin. The Nansen Basin and Amundsen Basin AUs encompass the deep abyssal plains of the Eurasia Basin. Lying south of the Gakkel Ridge spreading center, the sedimentary fill of Nansen Basin AU consists of the distal clinoform deposits shed from the western Eurasia passive margin. North of the Gakkel Ridge, Amundsen Basin AU consists of a nascent distal passivemargin sequence derived from the adjacent Lomonosov Ridge and overlying flat-lying deep marine strata shed from distant source areas in Siberia and Greenland after the Lomonosov Ridge subsided below sea level at about $50 \mathrm{Ma}$. The primary petroleum system thought to be present is sourced in $\sim 50-44$ $\mathrm{Ma}$ (early to middle Eocene) condensed pelagic deposits that could be widespread in the province.

Mean estimates of undiscovered, technically recoverable petroleum resources include $<1$ billion barrels of oil (BBO) and about 1.4 trillion cubic feet (TCF) of nonassociated gas in Lena Prodelta AU, and $<0.4 \mathrm{BBO}$ and 3.4 TCF nonassociated gas in the Nansen Basin Margin AU. Quantities of natural gas liquids and associated natural gas also are assessed in each of these AUs. The Nansen Basin and Amundsen Basin AUs were not quantitatively assessed because they were judged to have less than 10 percent probability of containing at least one accumulation of $50 \mathrm{MMBOE}$ (million barrels of oil equivalent), the minimum probability required for evaluation in the U.S. Geological Survey Circum-Arctic Resource Appraisal.

\section{Introduction}

The U.S. Geological Survey (USGS) in 2008 completed an appraisal of undiscovered, technically recoverable, conventional oil and gas resources north of the Arctic Circle. Results of that Circum-Arctic Resource Appraisal (CARA) include aggregate resource estimates for the entire Arctic region (Bird and others, 2008; Gautier and others, 2009, 2011a) and documentation of the geological framework and resource estimates for specific Arctic provinces (Bird and Houseknecht, 2011; Gautier and others, 2011b; Houseknecht and Bird, 2011; Houseknecht and others, 2012a, b; Klett and Pittman, 2011; Klett and others, 2011; Moore and Pitman, 2011; Moore and others, 2011; Schenk, 2011a, b; Sørensen and others, 2011). The procedures and methods used in conducting the CircumArctic Resource Appraisal are discussed in Charpentier and Gautier (2011) and Charpentier (2017, this volume) and the location and extent of the basins evaluated are delimited in Grantz and others $(2010,2011)$. The purpose of this chapter is to provide a synthesis of the petroleum geology of the Eurasian Basin Province, to present the reasoning and input parameters used for petroleum assessment of its constituent assessment units, and to report the complete results of the resource assessment for the province. 

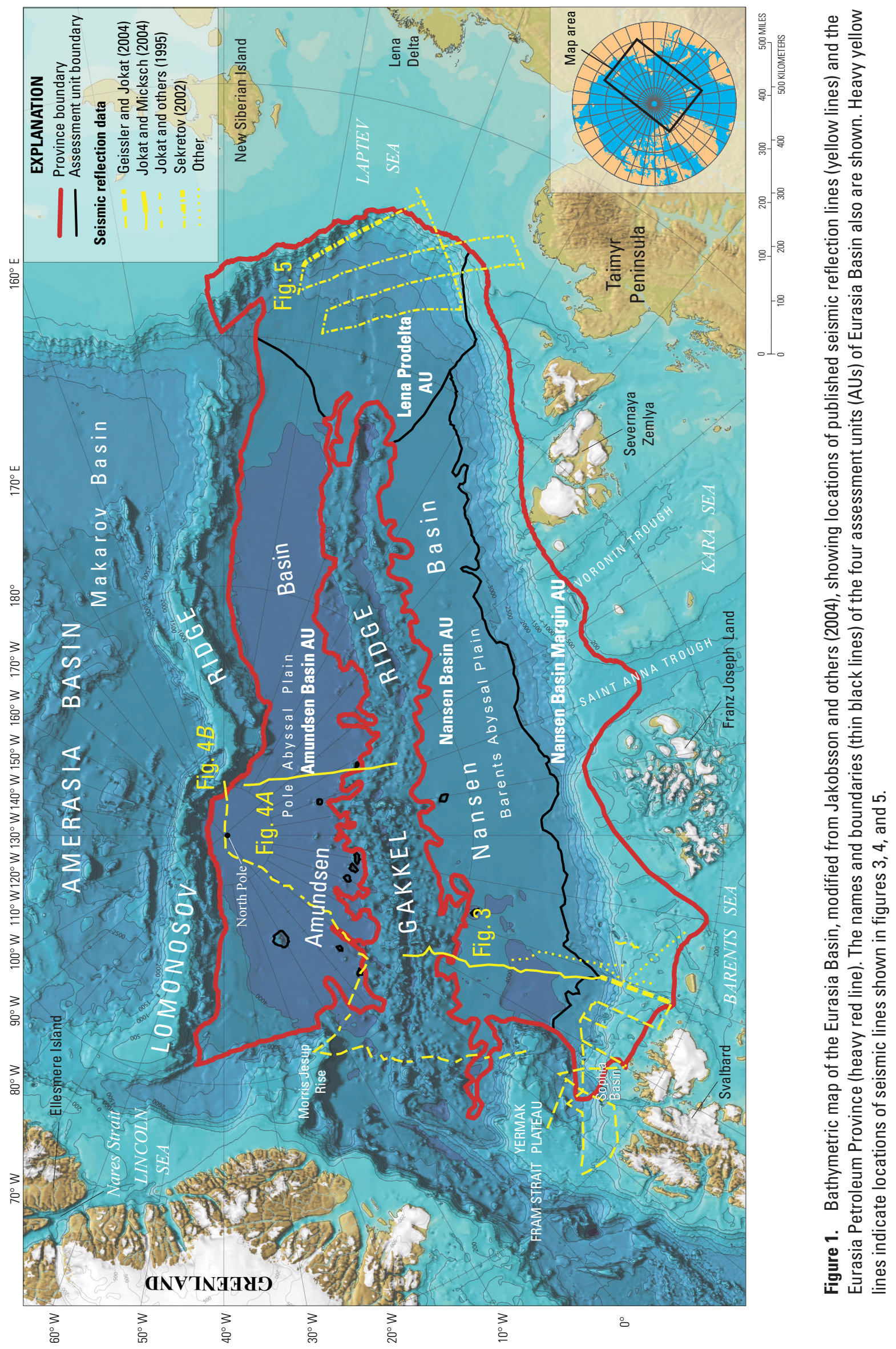


\section{Eurasia Basin Province Description}

\section{Boundaries}

The Eurasia Basin composes the eastern part of the Arctic Ocean basin between the continental margin of Europe and the submerged Lomonosov Ridge and includes the North Pole. As defined for the Circum-Arctic Resource Appraisal (CARA), the Eurasia Basin Province encompasses those parts of the Eurasia Basin that have significant sedimentary cover plus the Cenozoic deposits on the adjacent, outer part of the Eurasia continental margin between Svalbard and the Laptev Sea (fig. 1). The province includes the Pole Abyssal Plain in the Amundsen Basin, the Barents Abyssal Plain in the Nansen Basin, and other depocenters along the continental shelf edge and slope on the Barents, Kara, and Laptev Sea margins of Eurasia. The latter includes Sophia Basin, the outer Saint Anna Trough, the outer Voronin (Schmidt) Trough, and the Lena Prodelta. The southern margin of the province is defined as the updip limit of the Cenozoic continental terrace on the Eurasia continental margin in the south. The eastern margin is defined as the shelf-slope break of the continental margin in the Laptev Sea. The northern margin is the base of the continental slope of the Lomonosov Ridge, and the west margin is the westward limit of substantial thicknesses of sedimentary deposits against Morris Jessup Rise and Yermak Plateau in the Amundsen and Nansen Basins, respectively. The Eurasia Basin Province is bisected by the Gakkel Ridge, an actively spreading midocean ridge, which extends northward from the North Atlantic Midocean Ridge and separates the Amundsen Basin from the Nansen Basin. Although the ridge is largely barren of sediment along most of its length due to its young age, the eastern end of the Gakkel Ridge is covered by deposits shed into the Eurasia Basin from the Lena Delta in the Laptev Sea. Consequently, the Eurasia Basin Province displays a "V"-shaped map pattern that is open at its western end facing Greenland.

Defined in this way, the Eurasia Basin Province has a total area of $1,118,000 \mathrm{~km}^{2}$, with a length of 2,000 km and a width of 500-700 km. The province lies north of $80^{\circ}$ latitude except for the continental slope of the Laptev Sea where it extends south to about $77^{\circ}$ latitude. The province is entirely submerged at depths ranging from less than $200 \mathrm{~m}$ on the Eurasian continental margin to more than $4,000 \mathrm{~m}$ in the Amundsen and Nansen Basins. The province is bounded by the LomonosovMakarov Province to the north, the Barents Platform Province, East Barents Basins Province, Kara Sea and West Siberia Province, and Northwest Laptev Sea Shelf Province on the south, and the Laptev Sea Province on the east.

\section{Geologic Setting}

The Eurasia Basin is a historically ice-covered ocean basin that formed by seafloor spreading of the Lomonosov Ridge away from the Barents-Kara Sea continental margin of
Eurasia beginning at 56-58 Ma and continuing today (Vogt and others, 1979; Brozena and others, 2003; Glebovsky and others, 2006). Magnetic isochrons are well developed in the basin and document a close fit between the Lomonosov and Barents continental margins, indicating that the basin was formed by slightly asymmetric orthogonal spreading beginning at anomaly 24 or possibly 25 time (Vogt and others, 1979; Brozena and others, 2003; Glebovsky and others, 2006) (figure 2). The spreading axis for the basin is the Gakkel Ridge, an ultraslow spreading center that displays the slowest rate of spreading on the Earth $(0.59 \mathrm{~cm} / \mathrm{yr})$ (Vogt and others, 1979). Aeromagnetic anomalies indicate that prior to $33 \mathrm{Ma}$, the Gakkel Ridge had a somewhat faster rate of spreading $(1.1 \mathrm{~cm} / \mathrm{yr})$ (Vogt and others, 1979), although still considered to be slow relative to midocean ridges worldwide. Characteristics of ultraslow spreading present in the Eurasia Basin include (1) thin (1.9-3.3 km) to mantle-dominated oceanic crust; (2) an absence of transform faults; (3) prevalence of discontinuous and point-source volcanic centers, (4) alternating magmatic and amagmatic ridge segments, (5) high levels of hydrothermal activity, and (6) rough (high-relief) basement topography (Cochran and others, 2003; Dick and others, 2003; Michael and others, 2003; Jokat and others, 2003).

Spreading rates decline smoothly eastward in the basin toward the present pole of rotation, which is located near the Lena Delta. The proximity of the pole of rotation to the Gakkel Ridge is thought to be the chief explanation for the ultraslow spreading rates in the Eurasia Basin. Higher rates of spreading occurred prior to 33 Ma probably because the pole of rotation had a more southerly location, possibly as far south as Japan (Drachev and others, 1998).

Although transform faults are mostly absent within the Eurasia Basin, the Gakkel Ridge is interpreted to terminate at a hypothetical transform fault, called the KhatangaLomonosov Fracture Zone by Drachev and others (2003), that lies buried beneath late Cenozoic strata along the Laptev Sea continental margin (fig. 2). The presence of a transform fault at this location is supported by the truncation of rift-related structures and seismicity trends and by a disparity between the total amount of extension calculated for the continental margin in the Laptev Sea and the eastern Eurasia Basin (Drachev and others, 1998, 2003; Franke and others, 2001). Drachev and others (2003) proposed 140-150 km of right-slip separation on the transform and concluded that seafloor spreading does not extend onto the Laptev Shelf.

The western end of the Eurasia Basin displays a complex tectonic history that probably involved large-displacement transform faults. Since magnetic anomaly 10 (33 Ma), seafloor spreading in the basin has been linked to the North Atlantic spreading centers via a series of short spreading centers located in the Norwegian-Greenland Sea. Prior to $33 \mathrm{Ma}$, the time at which seafloor spreading began between the Yermak Plateau and Morris Jesup Rise, the Eurasia Basin probably terminated at a transform fault or triple junction located on the eastern side of the combined plateaus. This transform fault may have linked seafloor spreading in the Eurasia Basin to spreading in the Baffin Bay and Labrador Seas via the Nares 


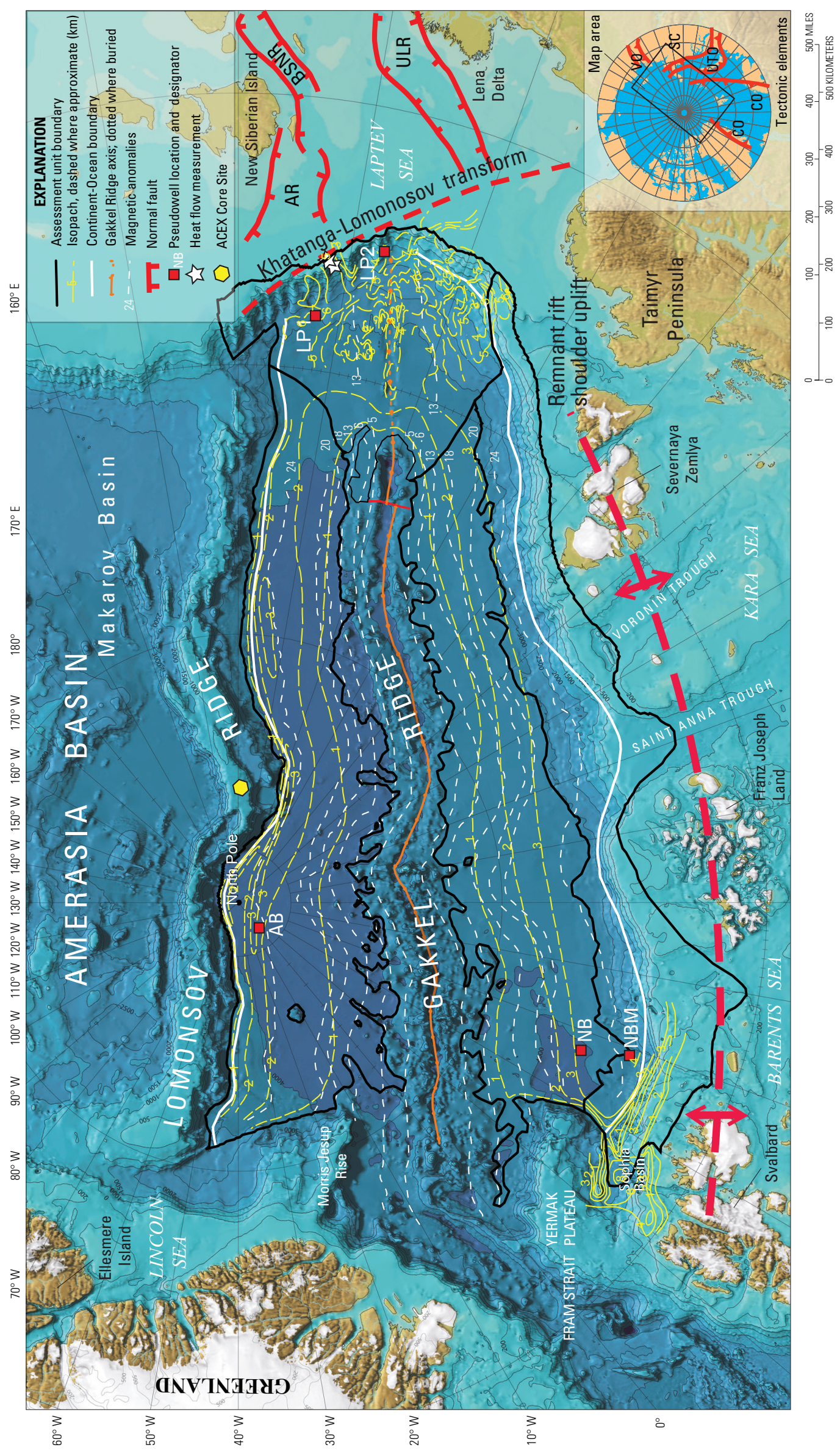

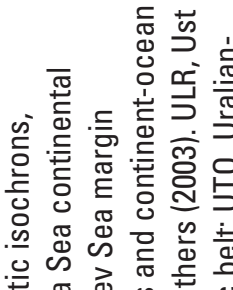

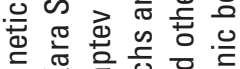

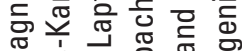

E

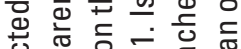

䊀

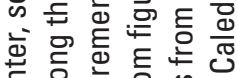

过

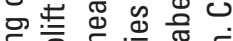

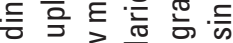

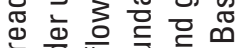

的

远

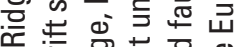

ब्ञ

竞

(1)

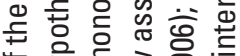

을 를 定

为

西

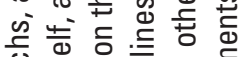

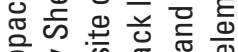

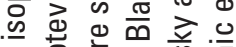

은

क论向递

里的心

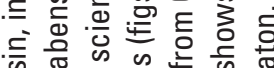

元

.

क

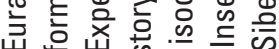

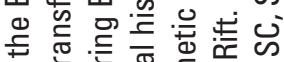

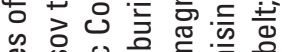

o d 은

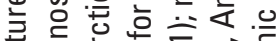

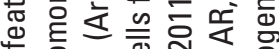

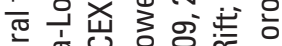

言运응 웅

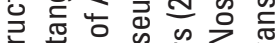

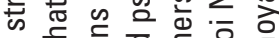

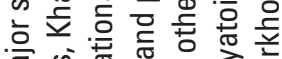

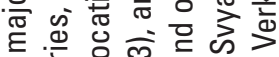

은 잉

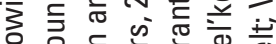

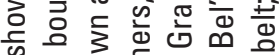

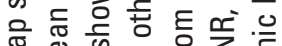

$\sum$ 잉

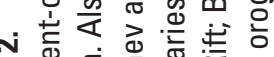

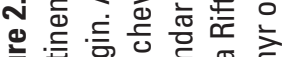

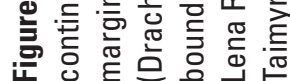


Strait in the Paleocene and Eocene (Brozena and others, 2003) and to a transform located between Greenland and Svalbard as well. Thus, a connection between the Eurasia Basin and the North Atlantic probably was not established until the Oligocene at the earliest.

Three major orogenic belts were truncated at high angle by the rifting that led to opening of the Eurasia Basin (Gee and others, 2006). One of these is the Silurian and Devonian Caledonian orogenic belt, which consists of deformed metamorphic and igneous rocks that trend northward from Scandinavia under the Barents Sea to Svalbard toward the margin of the western Eurasia Basin. The Caledonian belt records the collision of Laurentia and Baltica in the early Paleozoic and is unconformably overlain by a flat-lying post-deformational Carboniferous to Cretaceous platform sequence that contains rich Triassic and Jurassic source rock strata and carbonate and siliciclastic reservoir strata. This platform sequence has given rise to the Nordkapp and Hammerfest petroleum accumulations in the Norwegian Barents Sea.

The second orogenic belt is the Uralian-Taimyr orogenic belt, which underlies the continental shelf in the area of the northwest Laptev Sea at the eastern end of the Eurasia Basin. This belt consists of metamorphic and sedimentary rocks that were deformed mainly in the Permian and Triassic, but the belt includes structures as young as Jurassic in Taimyr.

Between the two belts is the foreland basin for the Uralian and Taimyr orogens. The foreland basin deposits trend northward from Timan-Pechora under the eastern Barents Sea to Franz Joseph Land and interfinger westward with the platform deposits under the western Barents Sea. The foreland basin actively subsided primarily in the Permian and Triassic, but it was significantly impacted by synchronous extension that formed the deep basins beneath the modern eastern Barents Shelf (O'Leary and others, 2004). Sediments shed from the Uralian orogen filled these basins in the Permian and Triassic, with deposition extending into the Jurassic and Early Cretaceous in Franz Joseph Land. The Saint Anna and Voronin (Schmidt) Troughs, which empty into deep-sea fans in the Eurasia Basin east of Franz Joseph Land, may be interpreted as the Cenozoic expression of the foreland basin. The forelandbasin deposits contain the giant Shtockman gas deposit in the eastern Barents Sea and display numerous dikes and veins of bitumen in Franz Joseph Land.

The Caledonian and Uralian-Taimyr belts and intervening foreland basin were truncated at a high angle by rifting and opening of the Eurasia Basin in the late Paleocene. The northern extensions of the belts are likely present on the Lomonosov Ridge, a sliver of continental crust that forms the conjugate, northern flank of the Eurasia Basin. Grantz and others (2001) reported that cores recovered from the Lomonosov Ridge near the North Pole contain Jurassic or Cretaceous deposits similar to the foreland basin deposits in Franz Joseph Land, substantiating this interpretation.

The third major orogenic belt is the Cretaceous Verkhoyansk fold-thrust belt, which was probably truncated by the opening of the Eurasia Basin in the Laptev Sea (fig. 2, inset). This deformational belt involved westward thrusting of accreted terranes onto the western margin of the Siberian craton, but its location and character under the Laptev Shelf and hence at the continental margin is uncertain because of burial beneath Cenozoic syn- and postrift deltaic deposits of the Lena Delta.

The continental margin in the Laptev Sea is dominated by Tertiary horsts and grabens and extensional faulting caused by continental rifting related to seafloor spreading in the Eurasia Basin. Among these are the broad Ust' Lena Rift along the eastern margin of the Lena River Delta, the narrow Bel'kovSvyatoi Nos Rift along the western margin of the New Siberian island, and the broad Anisin Basin to the north (Drachev and others, 1998; Franke and others, 2001). Sedimentary fill in the grabens typically is $4-5 \mathrm{~km}$ thick, but to the north and east of the Lena Delta it is as much as $13 \mathrm{~km}$ thick (Franke and others, 2001) (fig. 2). Some workers have proposed that the deeper basins contain sedimentary deposits of Riphean to Mesozoic age (for example, Sekretov, 2002, and references therein), although other workers consider these sedimentary sequences to be no older than latest Cretaceous (Drachev and others, 1998, 2003; Franke and others, 2001). Drachev and others (1998) suggested that the sedimentary fill is consistently thinner eastward from one graben to another, a trend they attributed to a westerly decreasing graben age due to the westward movement of the Gakkel Ridge relative to the Laptev Shelf continental margin along the Khatanga-Lomonosov transform. The horsts and grabens were constructed primarily in the Paleocene and Eocene because younger extensional deformation was reduced by the northward migration of the pole of rotation into the Laptev Shelf area (Drachev and others, 1998).

\section{Eurasia Basin Stratigraphy}

Due to its remoteness and ice cover, the stratigraphy of the Eurasia Basin is poorly known, particularly in the region north of the Russian margin. Current understanding of the basin fill is derived from cores and geophysical data collected from drifting ice stations and, since 1991, a few icebreaker seismic reflection and refraction studies. These studies show that the Amundsen and Nansen Basins are asymmetric basins with flat abyssal plains and sedimentary sections that are thickest near their respective continental margins (Jokat and Micksch, 2004). The sedimentary deposits in Nansen Basin are at least $4.5 \mathrm{~km}$ thick near the Barents-Kara continental margin and wedge out northward onto the Gakkel Ridge, with oceanic crust younger than about magnetic anomaly 12 (33-35 Ma) being partly to mostly barren of sediment (Jokat and Micksch, 2004; Geissler and Jokat, 2004) (fig. 3). Sedimentary fill is thinner in Amundsen Basin than in Nansen Basin, having a thickness that ranges from 1 to $3 \mathrm{~km}$ (Jokat and others, 1995; Jokat and Micksch, 2004) (fig. 2). Strata in both basins onlap onto progressively younger oceanic crust toward the Gakkel Ridge, reflecting the position of the 
midocean ridge at the time of deposition of the strata. Basement topography in both basins is rough, with a relief of 1-2 $\mathrm{km}$, which is attributed to the slow rates of spreading (Jokat and Micksch, 2004). The continent-ocean transitions of both margins of the basin are characterized by down-faulted basement rocks rather than by seaward-dipping volcanic sequences. This indicates rifting was not accompanied by eruption of thick subaerial volcanic sequences (Geissler and Jokat, 2004; Jokat and others, 1995).

Sedimentary deposits in the Nansen Basin compose a continental rise and slope prism produced by sediment shed across the Barents-Kara Seas passive continental margin (fig. 3). These deposits form offlapping prisms on the outer parts of the continental margin with clinoforms that extend down the slope and well out into Nansen Basin. Submarine fans are evident in the bathymetry along the Barents-Kara Sea continental margin and probably were formed in part during lowstands in the Pleistocene when rivers carrying glacial sediment debouched near the continental margin. Sedimentary slumping, slide scars, and deeply incised canyons are common in slope deposits along the margin leading to a rough slope topography (Geissler and Jokat, 2004). These deposits are the product of a large flux of sediment transported across the continental shelf from the vast source areas in the Eurasia continental plate throughout the Cenozoic. The sedimentary fill of the Sophia Basin, more than $9 \mathrm{~km}$ thick, is much greater than that of the Nansen Basin, leading Geissler and Jokat (2004) to suggest that Sophia Basin may have formed initially as a rift basin in the Late Cretaceous prior to separation of the
Lomonosov Ridge away from the Barents-Kara Sea continental margin. Gravity lows elsewhere along the margin (Geissler and Jokat, 2004) may indicate the presence of similar basins.

The sediment prism along the Lomonosov Ridge continental margin of the Amundsen Basin is diminutive compared to that of the Barents-Kara Sea continental margin (Jokat and others, 1995). The Amundsen Basin continental margin prism was produced by sediment shed from source areas of relatively limited extent on the Lomonosov Ridge. Continental margin sedimentation ended at about $50 \mathrm{Ma}$ at the time of subsidence and submergence of the Lomonosov Ridge (Jokat and others, 1995). Since that time, sediment deposited in the Amundsen Basin consists of hemipelagic and pelagic deposits and distal turbidites derived from source areas in Siberia and Greenland (Jokat and Micksch, 2004; Kristoffersen and others, 2004). Consequently, younger, flat-lying pelagic and hemipelagic deposits have buried the nascent continental slope and rise deposits and onlap the Lomonosov Ridge continental margin with a thin section of pelagic deposits draping the ridge (fig. 4). Jokat and others (1995) estimated that the upper $600 \mathrm{~m}$ of sediment in the basin represent more than 40 m.y. of deposition because of the slow rate of sedimentation following submergence of the ridge.

The thickest sedimentary prism in the Eurasia Basin is the Lena Prodelta, which fills the southeastern end of the basin, burying the Gakkel Ridge and abutting against the Laptev Sea Shelf from the Lomonosov Ridge to the Taimyr Peninsula (fig. 5). These sediments have been shed from the Lena Delta across the Laptev Sea Shelf and into the Eurasia

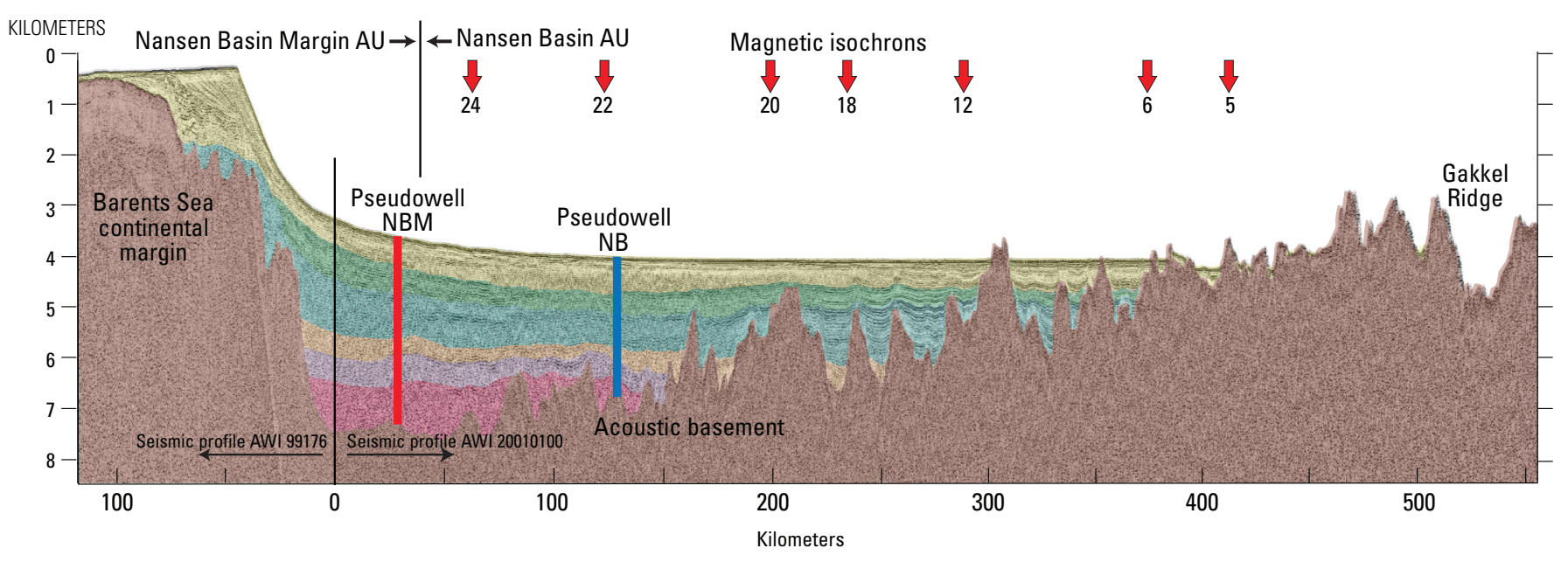

\section{EXPLANATION}

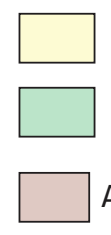

Unit I

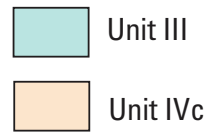

Unit II

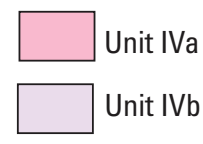

Acoustic basement
Figure 3. Seismic data and interpretation of Nansen Basin Margin and Nansen Basin Assessment Units (AUs). Depth scale relative to sea level. Explanation for colors shown in figure 6, column D. Diagram modified from Jokat and Micksch (2004). 
$\boldsymbol{A}$

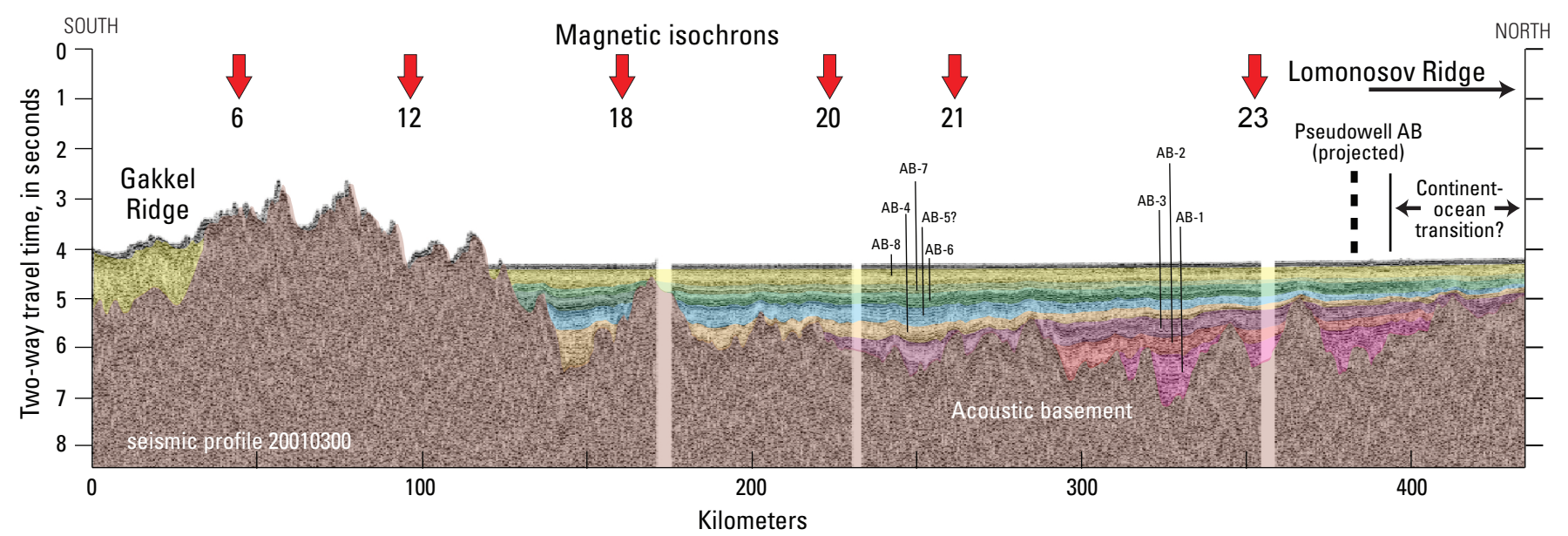

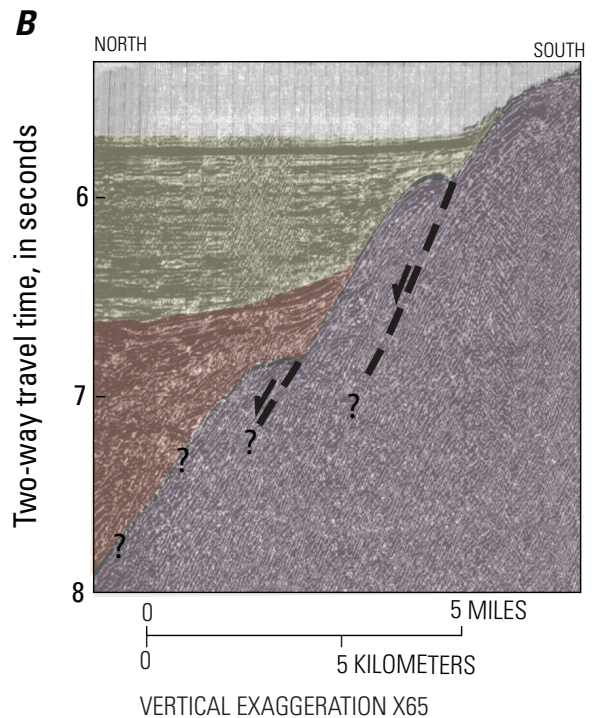

Figure 4. Seismic data and interpretations of Amundsen Basin Assessment Unit. See figure 1 for locations. A, Seismic profile 20010300 modified from Jokat and Micksch (2004). Approximate positions of units $A B-1$ to $A B-8$ projected onto profile from Jokat and others (1995). Depth scale relative to sea level.

Seismic units $A B-3$ to $A B-8$

Seismic units $A B-1$, Explanation for colors in figure shown in figure 6 , $A B-2$, and $A B-3$

Lomonosov Ridge column E. B, Part of seismic profile 91097 collected close to the Lomonosov Ridge, modified from Jokat and others (1995). Seismic units AB-1 to AB-3 constitute locally derived passive-margin sequence of Lomonosov Ridge deposited before its submergence at $\sim 50 \mathrm{Ma}$; seismic units AB-4 to AB-8 were deposited following submergence of the ridge and consist of flat-lying sediments that were probably shed from Greenland and (or) Siberia.

Basin, forming a delta second in size only to the Mackenzie River Delta in the Arctic Ocean. Rivers emptying through the Lena Delta drain much of central Eurasia, producing a total fluvial discharge that is the ninth highest in the world (Dai and Trenberth, 2002). The deltaic sediments fill the rift grabens of the Laptev shelf and spill across the continental margin into the ocean basin, where the Lena Prodelta is located. The sedimentary strata in the prodelta are typically 1.5 to $8 \mathrm{~km}$ thick with the thickest successions being located at its eastern and western margins where the oceanic crust is oldest and deepest (Sekretov, 2002). Nansen Basin in this part of the Eurasia Basin is shallower, has deeper basement, and has a thicker sedimentary section than does Amundsen Basin in the same area (Sekretov, 2002). On seismic profiles, the Gakkel Ridge, buried by sediments of the Lena Prodelta, is a high-standing block with irregular topography and a pronounced median rift valley. The thickness of the overlying sediments is as little as $0.4 \mathrm{~km}$ over the flanks of the ridge and up to 6-7 km above the rift valley (Drachev and others, 2003).
Utilizing the same seismic data set, Sekretov (2002) and Drachev and others (2003) arrived at different stratigraphic, structural, and tectonic models for the Lena Prodelta (fig. 6, columns F and G). Sekretov (2002) proposed that all oceanic crust in the southern part of the Eurasia Basin was created between 56 and about $33 \mathrm{Ma}$ and that the Gakkel Ridge has been an inactive, passive structure since $33 \mathrm{Ma}$ owing to the northward change in the pole of rotation for seafloor spreading at that time. Citing relations in the seismic reflection data, seismicity, high heat flow, and evidence of hydrothermal activity, Drachev and others (2003), on the other hand, concluded that the Gakkel Ridge has continued to actively spread since $33 \mathrm{Ma}$, although at a reduced, ultraslow, rate. Sekretov (2002) further suggested that rift basins filled with Carboniferous to Cretaceous strata of the Siberian platform underlie the Eurasia Basin deposits at deep structural levels adjacent to the northwest Laptev Sea Shelf, whereas Drachev and others (2003) considered these seismic units to be Late Cretaceous or Paleogene rift deposits. Utilizing different seismic stratigraphic 


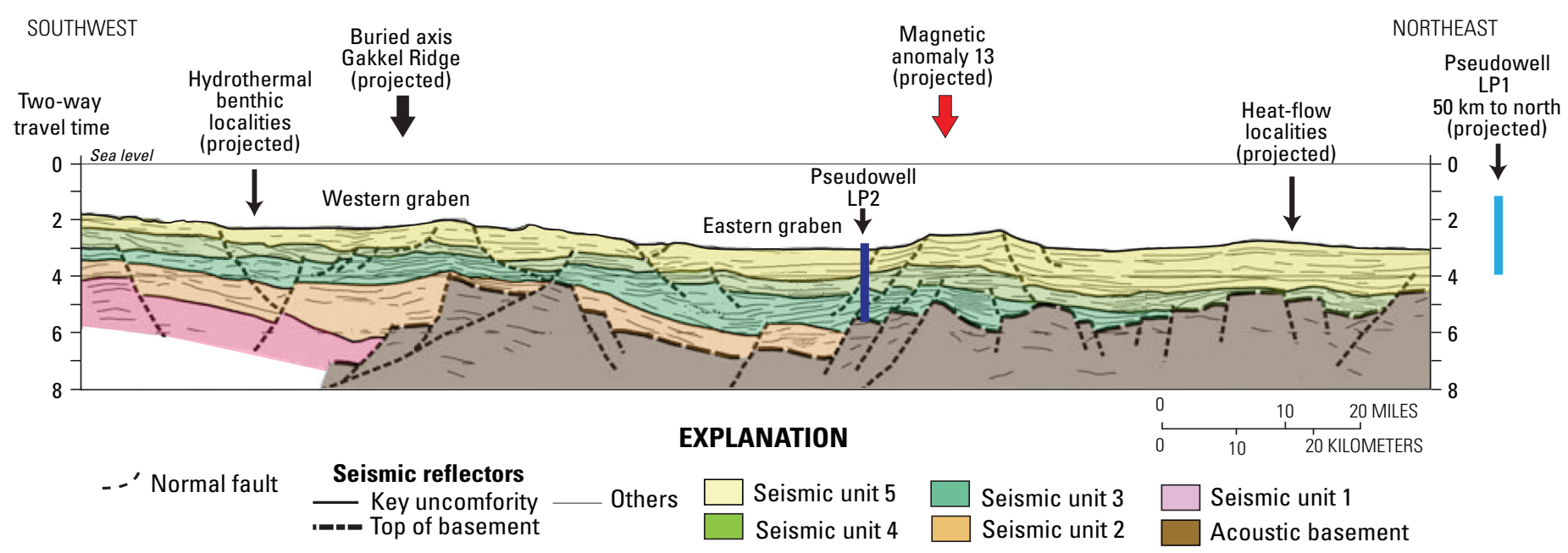

Figure 5. Seismic interpretation of strike line MAGE-90704 in Lena Prodelta Assessment Unit. Diagram modified from Drachev and others (2003).

models, these workers seem to agree on a generalized prodelta stratigraphy consisting of a lower section of latest Cretaceous to Paleocene terrestrial to lacustrine early rift deposits, a medial section of widespread late Paleocene to Oligocene syn-extensional submarine-fan deposits, and a upper section of mildly-deformed Miocene to Quaternary, glacially influenced submarine-fan deposits.

Because no wells have been drilled in the Eurasia Basin or its margins, most workers compare the stratigraphy of the basin to that of the Lomonosov Ridge as determined by scientific coring near the North Pole by the Arctic Coring Expedition (ACEX) of the Integrated Ocean Drilling Program (IODP) Expedition 302 (for example, Moran and others, 2006; Backman and others, 2008) (fig. 6, column A). The cores penetrated the entire 430-m-thick Cenozoic section on the Lomonosov Ridge, which is thin because it consists mostly of pelagic strata deposited atop the Lomonosov Ridge after separation from the Barents-Kara shelf at 56-58 Ma and subsequent subsidence below sea level.

The basal part of the ACEX section includes the regional rifting unconformity that separates the post-rift Cenozoic deposits above from prebreakup deposits below (O'Regan and others, 2008). Paleontologic data indicate prebreakup deposits are Campanian, and seismic data suggest the cored interval was taken from a tilted half-graben sequence (for example, Grantz and others, 2001; Backman and others, 2008). These relations suggest that the Campanian deposits represent the fill of a Late Cretaceous prebreakup rift basin that developed prior to the separation of the Lomonosov Ridge from the BarentsKara Sea Shelf.

Overlying the unconformity are $230 \mathrm{~m}$ of late Paleocene to middle Eocene (56 to $44 \mathrm{Ma}$ ) pelagic strata, including finely laminated, biosiliceous mudstone that is organic-rich (fig. 6 , column A). This section contains a fossiliferous interval characterized by enormous quantities of the freshwater fern Azolla that was deposited at $48.6 \mathrm{Ma}$. The high total organic carbon (TOC) content in the Paleocene to middle Eocene section probably resulted from condensed sedimentation in an euxinic environment caused by salinity stratification similar that of the modern Black Sea (Stein and others, 2006).

The lower part of the Cenozoic section on the Lomonosov Ridge is separated from the upper part by a disconformity that represents the period $\sim 44$ to $18 \mathrm{Ma}$ (Backman and others, 2008). This disconformity is associated with angular unconformities on the flanks of the Lomonosov Ridge (Y. Kristoffersen, oral commun., 2009). O'Regan and others (2008) suggested the unconformity was caused by regional tectonic uplift, but the absence of a locally derived, syntectonic, sedimentary prism of the same age in seismic data along the flanks of the Lomonosov Ridge argues instead for local, current-generated erosion, possibly due to upwelling or changes in circulation patterns due to opening of the Fram Strait. This interpretation is supported by a 6-m-thick color-banded interval of early Miocene deposits, whose cross lamination suggests current activity. Assuming these sediments were derived from the eroded section now missing beneath the disconformity, the high TOC content (up to 14 percent) of the Miocene deposits suggests that the missing section may have included significant thicknesses of condensed deposits.

Overlying the mid-Miocene unconformity, there is an abrupt transition to low TOC, fossil-poor, silty clays with interspersed sand lenses and dropstones in the upper part of the Cenozoic section. The sandy, low TOC deposits indicate a change at about 17.5 Ma to glacial conditions and full oxygenation of the basin, probably due to deep opening of Fram Strait (Jakobsson and others, 2007). This part of the section is $195 \mathrm{~m}$ thick and contains an upward-increasing amount of ice-rafted debris that records changes to seasonal ice conditions at about 


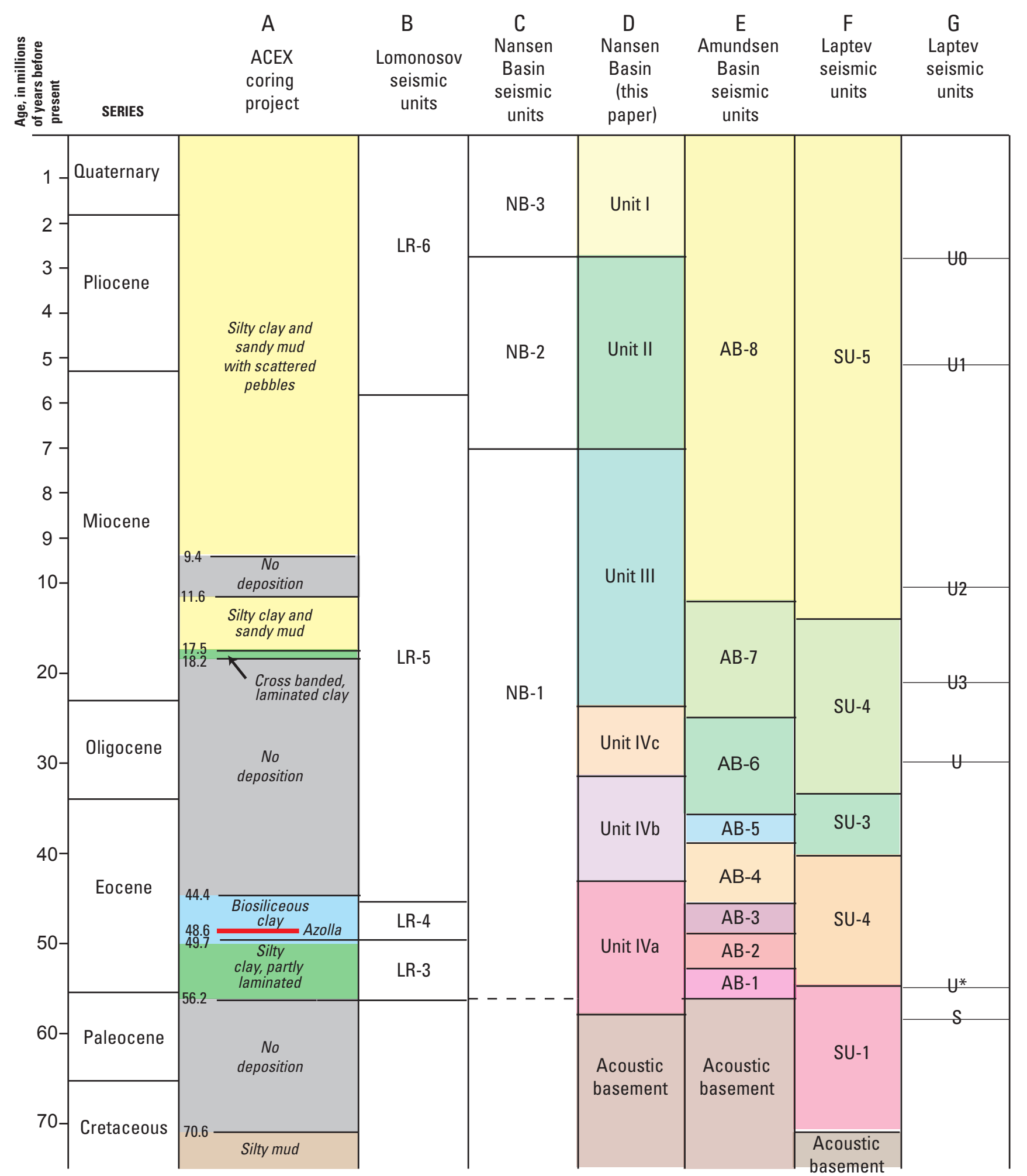

Figure 6. Stratigraphy at site of Arctic Coring Expedition (ACEX) and seismic stratigraphic models for Lomonosov Ridge and various parts of Eurasia Basin. Time scale nonlinear. Column A from Backman and others (2008) and Stein (2007). Gray shading indicates nondeposition or erosion; red line indicates Azolla interval; blue shading indicates interval displaying "good" quality source rocks of Mann and others (2009); green shading indicates other intervals where source rock strata are present; yellow shading indicates poor source rock quality. Columns $B$ and $E$ from Jokat and others (1995); stratigraphy of column $E$ is colored as in figure 4 and is used for burial history model of pseudowell AB (fig. 13). Column F from Drachev and others (1998) and colored as in figure 5. Column G, from Sekretov (2002), is used for burial history models of pseudowells LP1 (fig. 9) and LP2 (fig. 10). Column D, colored as in figure 3, shows stratigraphic age model constructed from Jokat and Micksch (2004) and is used for burial history models of pseudowells NBM (fig. 11) and NB (fig. 12). 
$14 \mathrm{Ma}$ and to expansion of continental ice sheets at $\sim 3 \mathrm{Ma}$ (Moran and others, 2006).

Backman and others (2008) showed that the sub-Miocene disconformity in the ACEX section corresponds to the top of a set of high-amplitude reflectors in seismic reflection profiles.

These reflectors can be traced laterally into the Amundsen and Makarov Basins and onto the East Siberian continental margin slope (Jakobsson and others, 2007). Mann and others (2009) used similar correlations to trace the condensed interval across the Amundsen Basin for the purpose of petroleum-system modeling. Because the reflectors mark widespread pelagic deposits that fell out of the water column, the ACEX cores potentially could be used as a guide for the interpretation of the age and depositional character of strata in seismic data for large parts of the Eurasia Basin. If present, the source rock interval may be increased in thickness by the presence of the 44- to 18-Ma section that is missing in the ACEX core due to erosion. The quality of the source rocks might be reduced, however, due to dilution resulting from interstratified hemipelagic deposits, including turbidites. A reduction of source-rock quality would be expected to be a particularly significant factor in the Lena Prodelta and in the slope and rise deposits along the BarentsKara Sea continental margin where turbiditic hemipelagic deposits dominate the stratigraphic section.

\section{Petroleum Systems}

There is no direct evidence of an active petroleum system in the Eurasia Basin Province. Geissler and Jokat (2004) reported "bright spots" in Neogene strata in seismic reflection data from the Sophia Basin that might be an indirect indicator of natural gas. Gas also was reported in post-Miocene strata that drape the adjacent Yermak Plateau to the west outside the province boundary (Stein and others, 1995; Geissler and Jokat, 2004). The petroleum system for these possible hydrocarbon indicators is uncertain.

The primary source rock unit that hypothetically might be present in the Eurasia Basin is the high-TOC Paleocene to middle Eocene section observed in the ACEX cores from the Lomonosov Ridge (fig. 6, column A). These deposits compose a condensed section thought to have been derived from pelagic sediments formed in an anoxic to euxinic, salinity-stratified Arctic Ocean at a time when the climate in the Arctic was warmer and the basin was isolated from the world's oceans (Brinkhuis and others, 2006). The sediments are organic rich because of high productivity of marine algae-type organic matter coupled with redeposited terrigenous organic matter from the margins of the basin (Stein and others, 2006). The deposits in the ACEX section have TOC contents of 1 to 6 percent and even higher contents (as high as 14 percent) in the 6-m-thick early Miocene interval above the sub-Miocene disconformity. Hydrogen indices (HI) range from 100 to 350 and indicate a mixed Type II/Type III (terrigenous and marine) source, although Type III (terrigenous) source rocks also are common in the Paleocene part of the section (Stein, 2007). The 110-m-thick early and middle Eocene ( $~ 50$ to $44 \mathrm{Ma}$ ) interval was classified as having mainly good to very good source rock potential, although gas prone, by Stein and others (2006) and Mann and others (2009). These strata are thermally immature at the ACEX core site on the Lomonosov Ridge and have not generated hydrocarbons owing to their shallow burial beneath less than $200 \mathrm{~m}$ of strata (Stein and others, 2006).

Because the early and middle Eocene deposits evidently were formed by basinwide pelagic sedimentation when the Arctic Ocean was an isolated ocean basin, these potential source rocks might be present across the entire Arctic Basin and its margins (Brinkhuis and others, 2006; Houseknecht and others, 2012c) (fig. 7). This interpretation is supported by the existence of condensed deposits, typically including the Azolla interval, in the Beaufort and Chukchi Seas in Alaska, Mackenzie River Delta, and in the North Sea. Such strata may be the source of petroleum in the Mackenzie River Delta and eastern Alaska Beaufort coast (Houseknecht and others, 2012c). If the early and middle Eocene source rock strata were deposited across the entire Arctic, conditions would be favorable for large-scale generation of petroleum throughout much of the Eurasia Basin, assuming sufficient thermal maturity.

Mann and others (2009) modeled the source rock characteristics of the Paleogene condensed interval in the Amundsen Basin using the seismic reflection profile of Jokat and others (1995). They reported that the accumulated thicknesses of lower and middle Eocene strata with good and very good source potential are greater in the Amundsen Basin (up to 250 $\mathrm{m})$ than on the Lomonosov Ridge $(<110 \mathrm{~m})$ due to higher sedimentation rates. If the late Eocene to early Miocene strata that are missing owing to erosion beneath the sub-Miocene disconformity on the Lomonosov Ridge are present in the Amundsen Basin and have good source rock characteristics, this thickness could be still greater. It is unclear whether the diluting effect of interspersed turbidites in the condensed section was accounted for in the model of Mann and others (2009). The presence of turbidites would have the effect of increasing the total thickness of the source rock interval and overall rates of sedimentation without adding to the net thickness of condensed source rock strata. Thus, the early and middle Eocene source rock interval may appear to be thicker in the basin but not contain additional thicknesses of deposits with source-rock characteristics.

It is important to consider that the early and middle Eocene source interval may not be present in the southern part of Amundsen Basin near Gakkel Ridge. This is because Paleogene strata in the basin downlap southward from the Lomonosov Ridge onto oceanic crust that is diachronous and younger to the south. Oceanic crust that is closer to the Gakkel Ridge than that of magnetic anomaly 19 would be too young for the early and middle Eocene condensed sediments to have been deposited. If, on the other hand, condensed sedimentation extended into the early Miocene as hypothesized above, then condensed deposits could underlie most parts of Amundsen Basin that has significant sedimentary cover.

Assuming that early and middle Eocene condensed sedimentation occurred throughout the Arctic, a similar pattern 


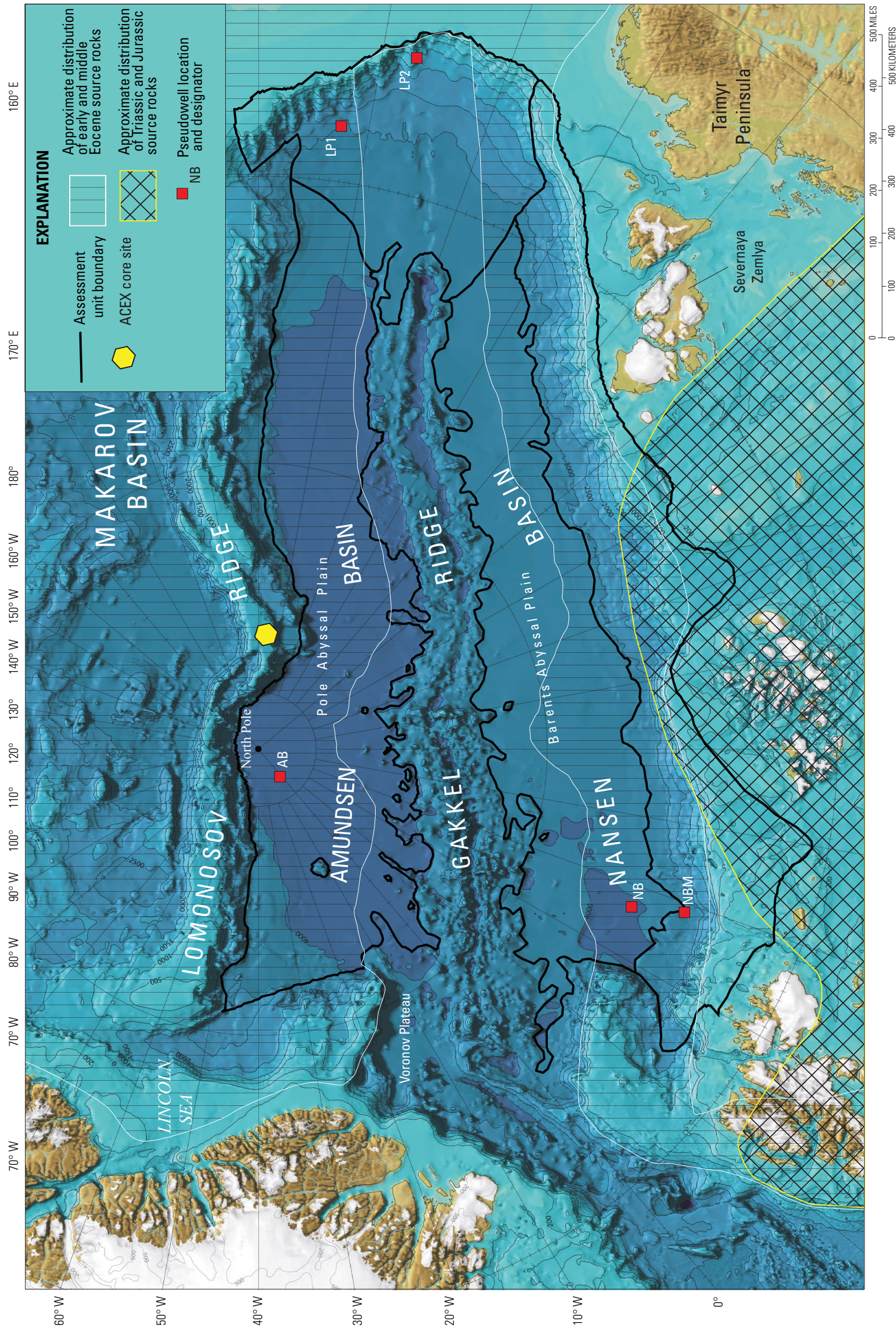

。焉贵

离言合

产号

œ

훙

$\stackrel{\circ}{\circ} \stackrel{0}{\circ}$

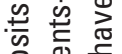

这

.0 $\overline{0} \stackrel{0}{0}$

要

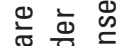

竞

등 웅

思㠿

言总

象

ब西

安 울

음 등 흠

两

元

츤 든

山. 氙

较完

๑ ब

舴

西

焉。

प등

吝要

눙

$\subseteq \frac{\pi}{2}$

तٓ त

跑

등

을 을

过志

휴 $\frac{0}{\mathrm{~N}}$

능

.들 吾

专㐫

든 응

武

¿ స

䒕

高

인 으

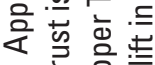

ㄱ. 응

일 京京

矛过苋 
and quality of source rock strata with respect to the Gakkel Ridge could be anticipated to be present in Nansen Basin. Higher sedimentation rates, however, are calculated along the Barents-Kara continental margin, which might significantly dilute the overall quality of the source rock strata there. If the increased rate of sedimentation was due to deposition of turbidites derived from the continental margin, the thickness of condensed deposits might be similar to that in the Amundsen Basin, but have a higher total thickness because of being interstratified with significant thicknesses of hemipelagic deposits. It is also possible that condensed sedimentation in this part of the basin has been mostly or entirely overwhelmed by hemipelagic deposition, resulting in degradation of the source rock potential of the interval. Global sea level was very high during the Paleogene and if sea level in the Arctic was in communication with global levels there would be an increased likelihood that terrigenous clastic sediment was mostly sequestered on proximal shelf areas and that dilution of organic carbon in outer shelf and off-shelf areas was minimal especially during times of sea level highstand conditions.

Other source rocks that might be present locally in the Eurasia Basin Province include Triassic and Jurassic condensed deposits of the Barents Shelf along the Barents-Kara Sea continental margin (fig. 7). North of Franz Joseph Land, a 5 -km-thick section of $3.7 \mathrm{~km} / \mathrm{s}$ upper Paleozoic(?) to Cretaceous strata is interpreted to be present beneath $1 \mathrm{~km}$ of younger strata in seismic data (Kristoffersen, 2000), suggesting the presence of such strata in the province. In Franz Joseph Land, thick units of Middle Triassic argillite and Upper Jurassic shale have yielded $0.93-2.68$ and 7.12 percent TOC, respectively (Bezrukov, 1997; Klubov and others, 2000).

Source rocks in the Lena Delta may include condensed strata deposited during times of high sea level stands. Sekretov (2002) reported evidence for multiple submarine fan complexes in seismic reflection data. The shale units that intervene between the complexes could be interpreted as condensed sediments deposited during the high stands. Deposition of icerafted sediment starting at about $18 \mathrm{Ma}$, however, would be expected to have significantly reduced the source rock quality of any condensed strata deposited since that time.

A key factor in determining the generative potential of the hypothetical source rock intervals discussed above is their thermal maturity, which is directly linked to the heat-flow the sediments have experienced through time. There are few thermal maturity data from the Eurasia Basin, and even less is known about the thermal history of the basin. Thermal maturation might be complicated because of heat-flow variability through time and space due to the seafloor spreading at Gakkel Ridge. Near the ridge, for example, heat flow in the basin should be extremely high due to the addition of new oceanic crust, whereas away from the ridge heat flow should be diminished because the basin is underlain by older, cooler oceanic crust. Accordingly, as sedimentation begins at a spot near the spreading center, accumulating sediments should be subjected to steadily diminishing heat flow through time as the underlying crust moves farther away from the site of active spreading.

Heat flow measured at midocean ridges typically diminishes asymptotically away from the ridge (McKenzie, 1967). This observation suggests that a similar change might be expected with time through a stratigraphic section deposited on oceanic crust. For this reason, we have assumed variable heat flow through time following the curves of Wei and Sandwell (2006) in the calculation of burial history models in this paper. Drachev and others (2003) measured the heat flow on the Laptev Sea continental slope at $85-117 \mathrm{mWm}^{-2}$, and calculated that these strata were deposited on oceanic crust of $43 \mathrm{Ma}$ age. This level of heat flow is appropriate for 43-Ma crust according to Wei and Sandwell (2006), supporting use of their heat-flow-with-age model in the Eurasia Basin. Their model suggests that at the time of formation of oceanic crust the initial heat flow is about $250 \mathrm{mWm}^{-2}$, whereas the heat flow for 60-Ma crust is about $70 \mathrm{mWm}^{-2}$, values that we have accepted as the maximums and minimums for the burial history modeling presented in this paper. The minimum level of heat flow is similar to that of the continental crust under the Barents Sea.

Mann and others (2009) accepted the heat flow data of Drachev and others (2003) as representative for the Gakkel Ridge, but they assumed the heat flow was constant across the entire Eurasia Basin throughout the duration of sedimentation (that is, since $56 \mathrm{Ma}$ ). Due to the lack of data or wells in the basin, it is unclear whether the heat flow model used in this paper or the one used by Mann and others (2009) yields more accurate results. The validity of models of the generative capability of the basin hinge to a significant degree on this decision.

The seawater interface temperature and paleowater depth boundary conditions used in the burial history modeling also were assumed to decline as a function of age. However, in contrast to heat flow, these parameters are based on the age of the Eurasia Basin as a whole rather than the age of oceanic crust that underlies each model location (that is, pseudowell). This assumption stems from the interpretation that the Eurasia Basin rifted and opened at approximately the same time throughout the basin, an interpretation required by the Khatanga-Lomonosov transform at the eastern end of the basin and by the Paleogene age of rifting on the Laptev Sea Shelf. If, on the other hand, the Eurasia Basin had opened along a propagating rift, a major transform fault such as the KhatangaLomonosov transform would not be expected to be located so close to the pole of rotation for the basin. In addition, extensional faulting on the Laptev Shelf should have increased in the Neogene, which seems to be contradicted by the seismic observations of Drachev and others (1998) and Franke and others (2001). For this reason, the boundary conditions for paleo-water depth and seawater interface temperature are assumed to be the same, although declining with time, at every pseudowell in the basin in the burial history models. 


\section{Assessment Units}

The assessment units defined for this study closely follow the structural domains of the Eurasia Basin (fig. 1) because they control the location, extent, and configuration of sedimentary basins that may be prospective for hydrocarbons (Grantz and others, 2010, 2011). The thickness, stratigraphy, facies, burial history, and structural evolution of the basins affect the size, number, and timing of formation of potential petroleum traps and petroleum generation and migration in the province. For purpose of petroleum resource assessment, the Eurasia Basin is divided into four assessment units (AUs) on the basis of its large-scale structural domains and physiographic features (fig. 1). The four assessment units are (1) Nansen Basin AU, (2) Nansen Basin Margin AU, (3) Amundsen Basin AU, and (4) Lena Prodelta AU (fig. 1). A lithostratigraphic column and events chart summarizing the petroleum geology of the Eurasian Basin Province and the constituent AUs is shown in figure 8 . The potential petroleum resources of these AUs are evaluated separately in the following sections.

\section{Lena Prodelta Assessment Unit}

The Lena Prodelta AU contains no petroleum exploration wells and extremely sparse seismic data. This level of exploration places the Lena Prodelta into uncertainty category 4 on the scale used by the USGS for the Circum-Arctic Resource Appraisal (Charpentier and Gautier, 2011) (appendix 1).

\section{AU Description}

The Lena Prodelta AU encompasses the prism of sediment shed onto the continental slope and rise of the southern Eurasia Basin from the Laptev Sea Shelf (figs. 1 and 2). Its southern margin is the Laptev Sea shelf-slope break and its northern margin lies at northern depositional limit of southderived sedimentary strata of significant thickness on oceanic crust near the Gakkel Ridge. The eastern and western boundaries of the AU are placed at bathymetric inflections that indicate the lateral extent of sedimentary deposits that were clearly derived from the Laptev Sea Shelf. In addition, the AU includes the part of the adjoining continental slope of the East Siberian Sea that drains into the Eurasia Basin, located north of the New Siberian Islands and south of the Lomonosov Ridge. Thus defined, the Lena Prodelta AU lies entirely north of the Arctic Circle and has an areal extent of $177,000 \mathrm{~km}^{2}$. It lies at water depths ranging from as shallow as $100 \mathrm{~m}$ on the Laptev Sea continental margin to nearly $4,000 \mathrm{~m}$ in the Eurasia Basin.

The AU includes the deep-water, prodelta portion of the modern Lena Delta, shed from the ninth largest river system in the world (Dai and Trenberth, 2002) and composing the second-largest delta to the Mackenzie River Delta in the Arctic Ocean. The AU consists principally of late Paleocene and younger strata deposited on the actively spreading Gakkel Ridge and adjacent oceanic crust of the Eurasia Basin between the Lomonosov Ridge and the Eurasia continental margin north of Taimyr. Along the continental margin, the AU may be underlain by crust that includes unmapped fault blocks of continental crust with pre-Cretaceous sedimentary cover and (or) Late Cretaceous to Early Paleocene rift basin deposits. Seismic reflection profiles indicate that sedimentary thicknesses in the AU range from less than $0.5 \mathrm{~km}$ over the flanks of the Gakkel Ridge rift valley to more than $8 \mathrm{~km}$ on old oceanic crust and (or) in rift grabens near the Lomonosov Ridge and Taimyr continental margins. The early and middle Eocene condensed deposits with good source rock characteristics and regional extent are expected to be present in areas with the thickest sedimentary successions.

\section{Geologic Model for Assessment}

The geologic model for the assessment of the Lena Prodelta $\mathrm{AU}$ is a petroleum system that was generated from mixed terrigenous and marine organic-rich early Tertiary pelagic deposits that accumulated when the entire Arctic Ocean was a stratified, euxinic basin isolated from the world's oceans. Petroleum could have been generated from these deposits because of burial beneath a thick prodeltaic section and relatively high heat flow due to the proximity of the Gakkel Ridge spreading center. The reservoirs are hypothesized to be slope and submarine-fan sandstones deposited by Cenozoic drainage systems that were generated in the mountain belts of central Eurasia. These deposits directly overlie and (or) interfinger with the source rocks. Stratigraphic traps in reservoirs composed of submarine-fan channel and lobe deposits and extensional fault traps related to seafloor spreading in the Eurasia Basin provided the sites for accumulation of petroleum.

\section{Geological Analysis of Assessment Unit Probability}

The probability that the Lena Prodelta AU contains at least one undiscovered accumulation equal to or greater than the minimum accumulation size of $50 \mathrm{MMBOE}$ prescribed by the methodology for the Circum-Arctic Resource Appraisal (Charpentier and Gautier, 2011; Charpentier, 2017, this volume) was determined from its geologic and petroleum system characteristics as reviewed below.

Charge.-Although there is no direct evidence of an active petroleum system in the AU, the good to very good quality source rocks of early and middle Eocene (50 to $44 \mathrm{Ma}$ ) age identified by scientific drilling on the Lomonosov Ridge are probably present beneath large parts of the AU adjacent to the continental margins of Nansen and Amundsen Basins. Assuming a simple model of seafloor spreading, strata of this age would be limited to those parts of the AU with oceanic crust older than magnetic anomaly 19. Although the relatively 


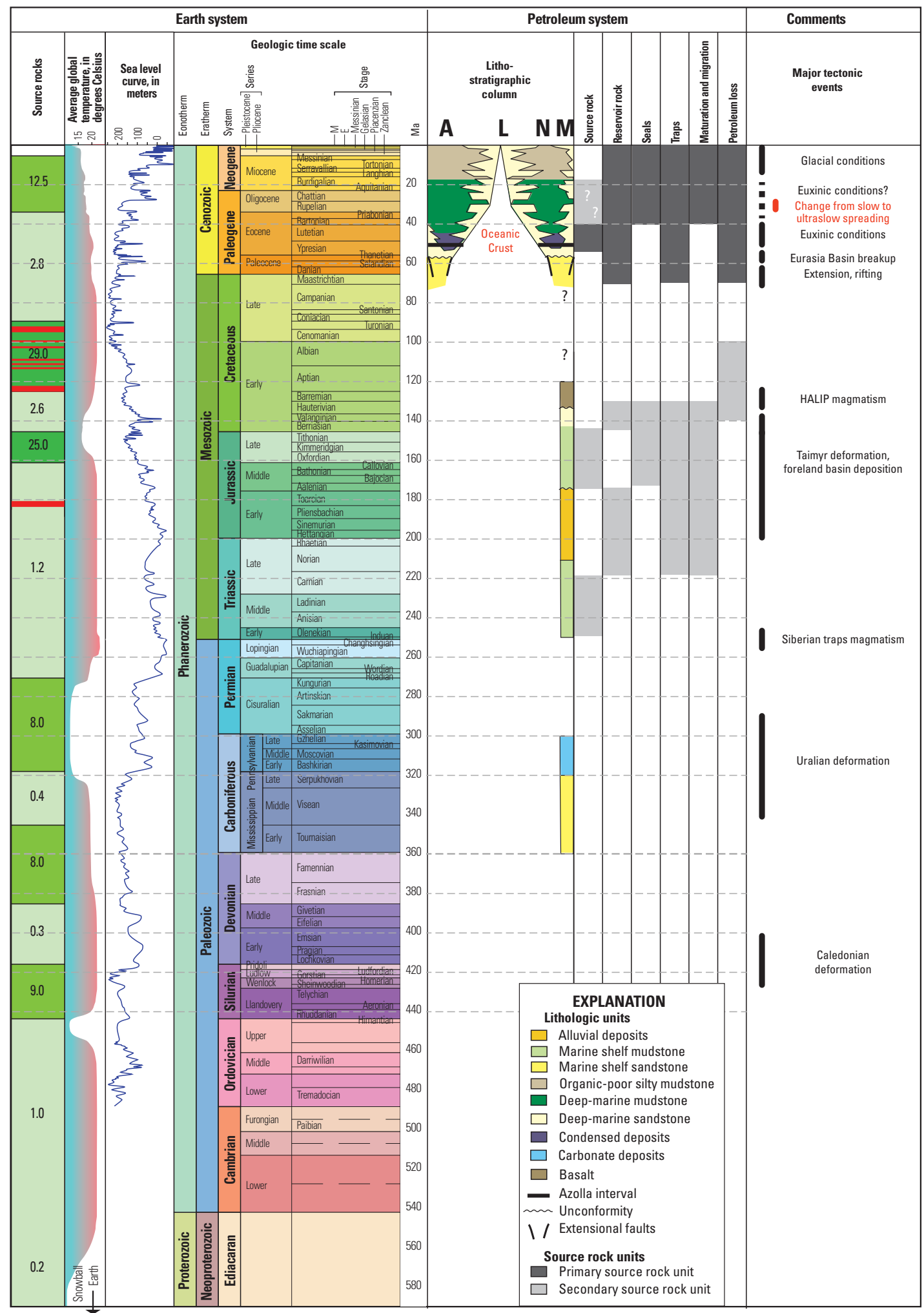

Figure 8. Lithostratigraphic column and total petroleum system events chart showing petroleum system elements for the Eurasia Basin Province. Data from Backman and others, 2008; Bezrukov, 1997; Brinkhuis and others, 2006; Cochran and others, 2003; Drachev and others, 1998, 2003; Embry, 1994; Jokat and others, 1995; Geissler and Jokat, 2004; Jokat and Micksch, 2004; Mann and others, 2009; Pease and Scott, 2009; Sekretov, 2002; Stein, 2007. Source rocks column shows the percent of the world's total petroleum reserves generated by source (modified from Ulmishek and Klemme, 1990). Average global temperature data is from Frakes and others (1992) and Barrett (2003). Sea level curve is from Golonka and Kiessling (2002) and Hardenbol and others (1998). Geologic time scale is that of Gradstein and others (2004). Geologic chart modified from P.J. McCabe (written commun., 2006). Abbreviations: A, Amundsen Basin Assessment Unit; L, Lena Prodelta Assessment Unit; N, Nansen Basin Assessment Unit; M, Nansen Basin Margin Assessment Unit; HALIP, High Arctic large igneous province. 
robust magnetic anomaly 13 has been identified in the AU, the positions of other magnetic anomalies under the Lena Prodelta AU have been difficult to locate owing in part to deep sedimentary burial beneath the deltaic sediments and possibly also to the localized nature of ultraslow seafloor volcanism. Projection from areas to the north where magnetic anomalies are known suggest that crust older than anomaly 19 should lie east of approximately $130^{\circ}$ longitude and west of about $120^{\circ}$ longitude (fig. 7). This region also corresponds to those parts of the AU with the thickest sedimentary section.

If condensed sedimentation continued into the early Miocene as the ACEX coring results suggest, source rock strata might extend closer to the Gakkel Ridge, probably to near magnetic anomaly 6 . Source rocks younger than about $18 \mathrm{Ma}$ seem unlikely in the AU because sedimentary conditions changed at about that time to more oxygenated environments marked by the steady deposition of ice-rafted debris. This type of deposition would tend to despoil the source-rock quality of the condensed-facies strata.

Seismic reflection data and isopach maps in the Lena Prodelta AU show that the top of oceanic basement ascends irregularly from depths of more than $8 \mathrm{~km}$ to less than $2 \mathrm{~km}$ toward Gakkel Ridge from both the Lomonosov and Taimyr continental margins (Sekretov, 2002; Grantz and others, 2010, 2011). We have constructed a one-dimensional burial history model at pseudowell LP1 in the Amundsen Basin part of the $\mathrm{AU}$ to investigate the thermal maturation of one of the thickest depocenters identified in seismic reflection data (figs. 2 and 9). A second pseudowell in the inner rift valley (pseudowell LP2; figs. 2 and 10) was modeled to investigate the thermal history close to the Gakkel Ridge. To perform this analysis, we have used the seismic stratigraphy of Sekretov (2002) (fig. 6, column G).

The location of pseudowell LP1, at the intersection of seismic lines 90704 and 90702 (Sekretov, 2002) in the Amundsen Basin, lies near the projected trend of magnetic anomaly 20 , suggesting that the oceanic crust underlying the sedimentary section there was formed at about $46 \mathrm{Ma}$. Because the early and middle Eocene source rock interval was deposited from $\sim 50$ to $44 \mathrm{Ma}$, this pseudowell should contain only the upper part of the interval. Thus, the source rocks should lie at or near the base of the pseudowell section and beneath the largest part of the thick prodelta clastic sequence in this area.

The burial history model for pesudowell LP1 (fig. 9) suggests that the early and middle Eocene source rock interval matured in the Eocene shortly after deposition, assuming a simple deposition history as outlined by Sekretov (2002). The entire source rock interval is modeled as currently overmature. If the source rocks include strata as young as Oligocene or Miocene, however, the younger parts of the source rock interval could lie in the oil window. At higher levels of heat flow such as that assumed by Mann and others (2009), even source rocks containing strata as young as Miocene would be expected to be overmature.

Pseudowell LP2 is located at shotpoint 1600 on seismic line 90704 (Sekretov, 2002) on an inner flank of the Gakkel
Ridge near the Laptev Sea continental margin where heat flow might be expected to be at or above the levels of $\sim 110^{\circ} / \mathrm{m}^{2}$ measured by Drachev and others (2003). Assuming this level of heat flow, source-rock strata deeper than $2 \mathrm{~km}$ are likely to be overmature (fig. 10). Given the location of the pseudowell near the spreading center, all of the strata are likely to be late Miocene and younger and thus unlikely to contain source rock strata.

On the basis of this analysis, a probability of 0.6 was assigned for the charge parameter for the Lena Prodelta AU. This level of uncertainty reflects the probable presence of good quality source rocks in some parts of the AU, although they could be overmature because of the high heat flow associated with deposition near an active midocean ridge and subsequent burial beneath a thick section of clastic strata. As in other Tertiary deltas, vertical migration, perhaps along growth faults, and bed-parallel, updip migration away from the areas of generation and into regions of lower thermal maturity can be expected in this AU. In addition, the depth of burial of source rock strata is variable in the AU because of the high relief of the underlying oceanic crust, allowing the possibility that the source rocks are currently in the oil window in some areas. The level of uncertainty also reflects (1) the possibility that the entire system has been flushed by large quantities of thermogenic gas generated at depth such that no oil accumulations are preserved in the AU and (2) a general lack of knowledge about the depositional and paleoheat flow characteristics of ultraslow-spreading tectonic environments. The hypothetical petroleum system in the Lena Prodelta is classified as the Lena Prodelta Cenozoic composite total petroleum system (appendix 1).

Rocks.-Reservoir rocks in the Lena Prodelta AU are completely unexplored but are expected to contain lithic-rich siliclastic turbidites similar to those found in the deepwater parts of other major modern deltas. Sekretov (2002) noted several overlapping submarine fan complexes in seismic data and described channels, updip truncations, downlaps, slumps, erosional unconformities and extensional faults that would provide good stratigraphic and structural trapping geometries. The potential also exists for slope basins formed by growth faulting or by mass failure and deposition of shallowly buried pods of sandstone in ponded basins. These trap types seem likely to contain coarse-grained reservoir facies because the drainage basin that feeds the Lena Delta includes several major mountain belts, the Siberian craton, and covers much of north-central Eurasia. In addition, Drachev and others (1998) described several major unconformities in the Tertiary deltaic deposits in coastal areas in the Laptev Sea and proposed that they represent regional lowstands of sea level. If correct, the lowstands would have allowed large influxes of coarse-grained sediment to be delivered directly into the deepwater parts of the delta that constitutes this AU. Low-stand deposits might be expected at 56, 52, 49, 40, 36, 29, 24, 22, 16, and $10 \mathrm{Ma}$ if such deposition was due to changes in global sea level (Miller and others, 2005). However, prior to about $17 \mathrm{Ma}$, the Eurasia Basin probably was isolated from the world's oceans; therefore, it is unclear whether lowstand deposition was responsive 


\section{Pseudowell LP1, Lena Prodelta AU, Amundsen Basin}

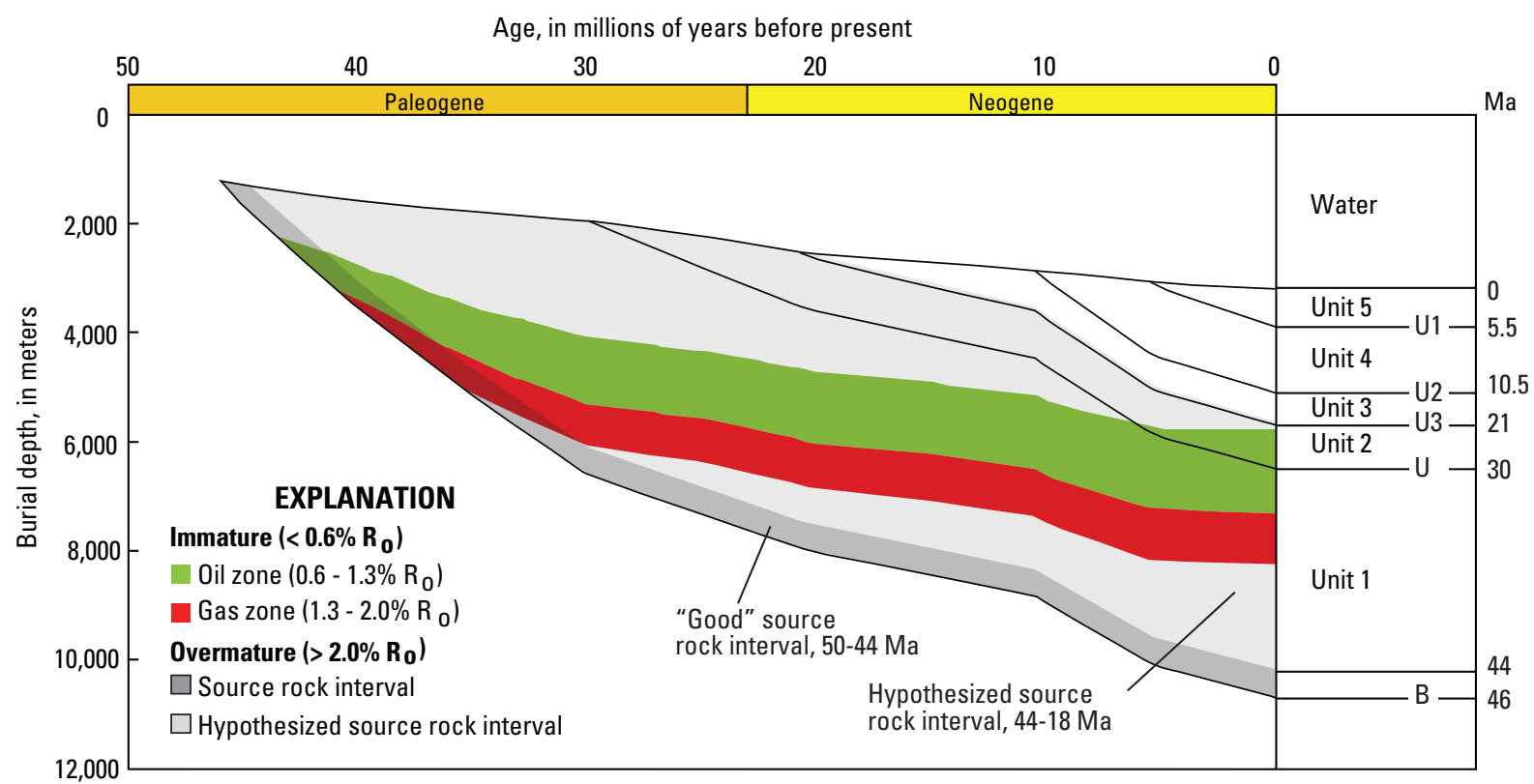

Boundary parameters

Age, in millions of years before present

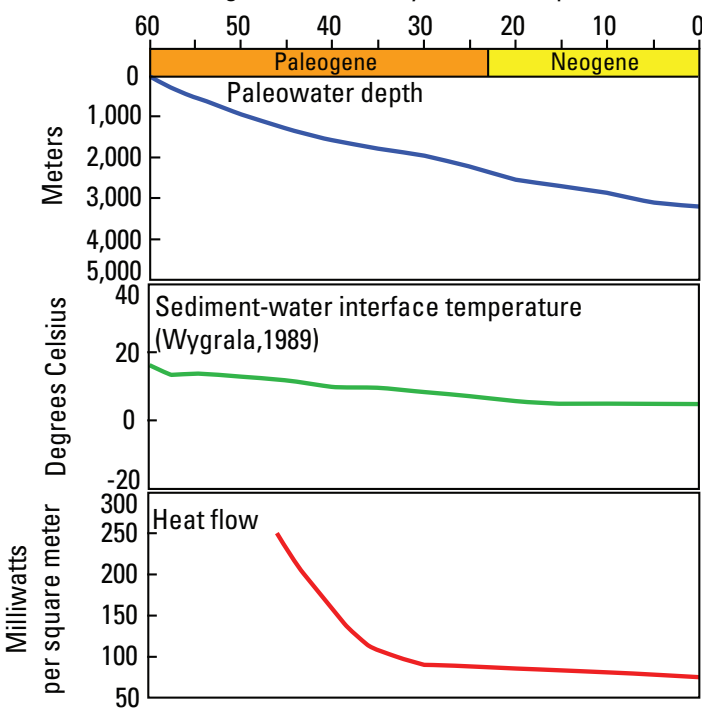

Temperature, in degrees Celsius

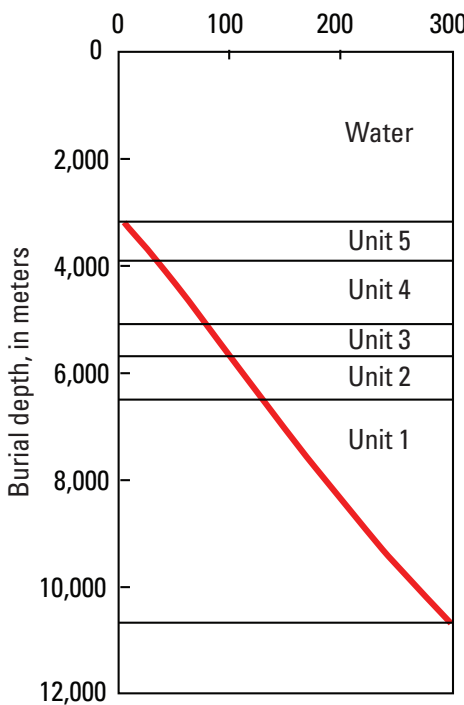

Easy $R_{0}$, in percent (Sweeney and Burnham,1990) $\begin{array}{lll}0.10 & 1.00 & 10.00\end{array}$

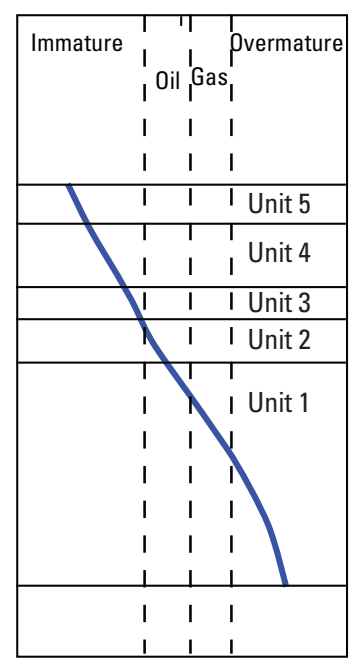

Figure 9. Burial history model for pseudowell LP1, located in a deep depocenter in Amundsen Basin in Lena Prodelta Assessment Unit (AU) (see fig. 2 for pseudowell location). Stratigraphic section, shown in figure 6, column G, is underlain by oceanic crust formed at $\sim 46 \mathrm{Ma}$. Projected stratigraphic position of good quality early and middle Eocene source rocks identified in Arctic Coring Expedition (ACEX) core from Lomonsov Ridge shown by dark gray shading; hypothetical source rocks possibly deposited during period of nondeposition or erosion on Lomonosov Ridge indicated by light gray shading. Model suggests that early and middle Eocene source rocks began to mature shortly after deposition and currently are overmature, whereas source rocks of Oligocene and Miocene age, if present, are presently in the oil window. 


\section{Pseudowell LP2, Lena Prodelta AU, Gakkel Ridge}

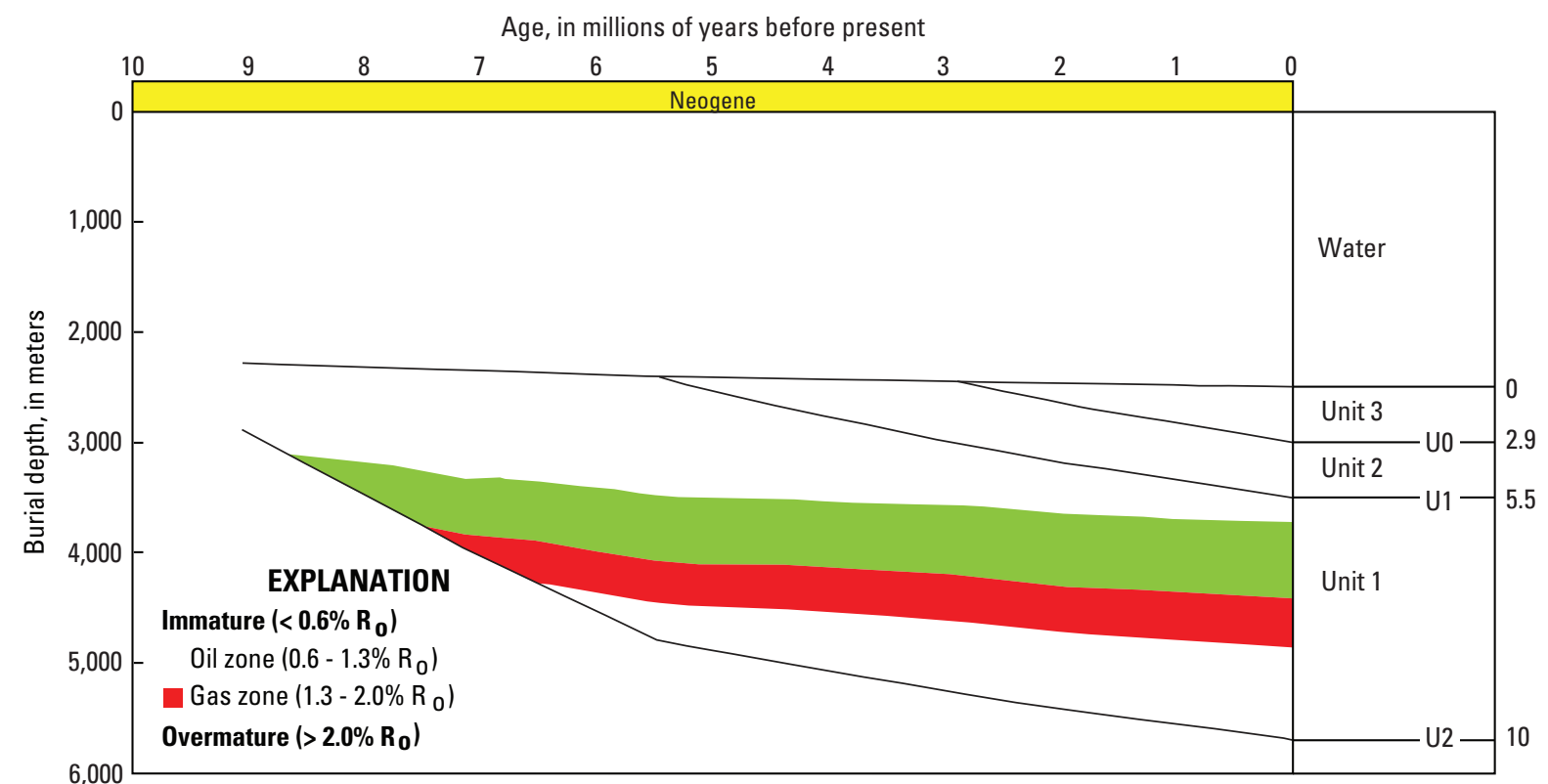

Easy $R_{0}$, in percent

Temperature, in degrees Celsius

(Sweeney and Burnham,1990)
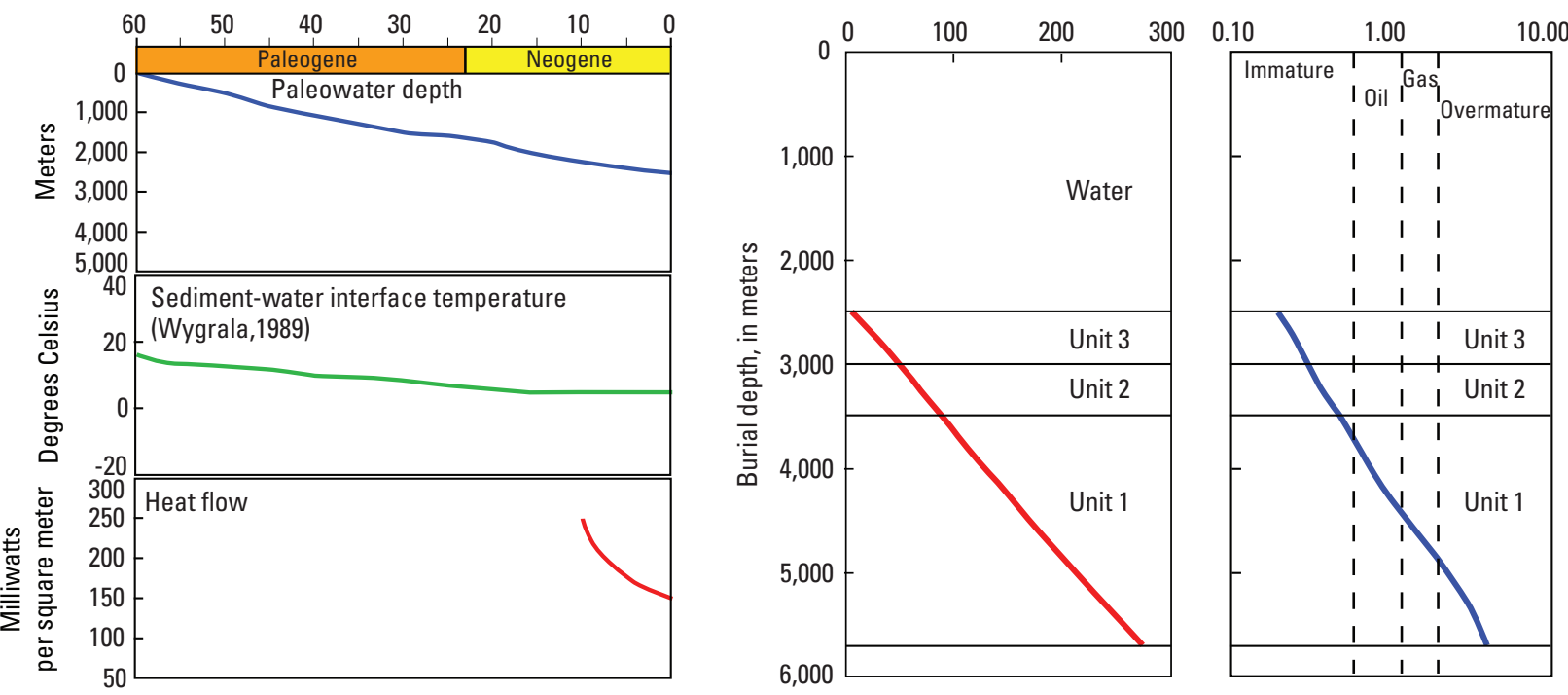

Figure 10. Burial history model for pseudowell LP2, located in central rift area of Gakkel Ridge in Lena Prodelta Assessment Unit (AU) (see fig. 2 for pseudowell location). Stratigraphic section (Sekretov 2002) underlain by oceanic crust formed at $\sim 10 \mathrm{Ma}$ from (fig. 6, column G). Model suggests that generation is possible even in areas underlain by young oceanic crust due to high heat flow. Source rock strata less than 10 Ma are unlikely, however, due to deposition of glacial sediments. 
to changes in global sea level.

Although good quality reservoir strata seem likely to be present, there is little information that would bear on their thickness and reservoir quality. As in the deepwater parts of other deltas, the coarse-grained deposits are assumed to be encased in hemipelagic mudstone that would provide good sealing geometries for most traps. Sandstones were derived in part from cratonal crystalline rocks, suggesting overall good reservoir quality. This information suggests generally favorable conditions for the existence of reservoirs, traps, and seals in the AU and accordingly, an uncertainty factor of 0.8 is assigned.

Timing and Preservation.-In the deeper depocenters near the Laptev Sea continental margin, the burial history modeling suggests that maturation of the early and middle Eocene source rock interval began in the late Eocene due to burial beneath deltaic sediments early in the history of the Eurasia Basin (fig. 9). Fluids expelled would have migrated into nearby recently formed stratigraphic traps, along active extensional faults into related structural traps, and updip into stratigraphic and combination traps on the margins of the depocenters. Generation probably advanced northward and away from the major depocenters during the Neogene as progressively younger offlapping sequences were deposited on the delta. The potential for preservation of hydrocarbon accumulations is excellent because of reduced tectonic activity as seafloor spreading moved to more distal locations relative to the depocenters and because the AU has continued to subside throughout its history. However, Sekretov (2002) reported local seismic reflection evidence for mafic igneous intrusions into the sedimentary succession in the AU that potentially could have had an adverse impact on the preservation potential of any accumulations. A favorable uncertainty factor of 0.9 was assigned for timing and preservation.

Overall Geologic Probability.-The geologic probability of the presence of an accumulation of minimum size in the Lena Prodelta AU, the product of the three geologic and petroleum system probabilities discussed above, is 0.432 (appendix 1). This level of probability suggests that there is a 43 percent chance that the proper conditions to form at least one oil or gas accumulation of the prescribed minimum size (50 MMBOE recoverable) exists in this AU. This probability, determined from the geology of the AU, was compared to the probabilities determined for the other AUs evaluated by the CARA project to ensure internal consistency. A favorable probability for the Lena Prodelta AU is consistent with those from the deepwater parts of deltas of major river systems, which generally are considered prospective for petroleum on a worldwide basis. Petroleum discoveries to 1998 in the Mackenzie delta, for comparison, are estimated to be $1.7 \mathrm{BBO}$ and $12 \mathrm{TCF}$ gas (Chen and others, 2007), with potential for substantially more resources (for example, Henry and others, 2006).

The overall probability of 43 percent for the Lena Prodelta $\mathrm{AU}$ is greater than the 10 percent minimum necessary for a quantitative assessment under CARA methodology (Char pentier and Gautier, 2011; Charpentier, 2017, this volume). Accordingly, an assessment of the sizes and numbers of undiscovered accumulations, the petroleum composition, and other properties was completed for this $\mathrm{AU}$ and is discussed below.

\section{Quantitative Assessment of Lena Prodelta Assesment Unit}

The assessment of the Lena Prodelta AU utilized the analog-based assessment methodology described in Charpentier and Gautier (2011; Charpentier, 2017, this volume) (appendix 1).

\section{Analogs Used in this Assessment}

Analog assessment units were selected from the USGS World Analog Database (Charpentier and others, 2008) for the purpose of estimating the number and sizes of undiscovered oil and gas accumulations in the Lena Prodelta AU. The analog AUs selected for use in this assessment consist of those with deltas and clastic slope, clinoforms, and turbidite depositional systems. This set of analogs was culled of those AUs containing salt structures because they are inappropriate for the Lena Prodelta AU, which doesn't contain salt deposits. The analog AUs selected for use in this assessment are the same as those provided in table 2 of Houseknecht and others (2012a).

\section{Numbers of Undiscovered Oil and Gas Accumulations}

The number of undiscovered accumulations was estimated from the discovered and undiscovered accumulations in the analogs normalized by area (that is, accumulation densities) as determined from the area and geologic characteristics of the Lena Prodelta AU. The median of the total accumulations was set at 45 , near the median for the overall analog group. In view of the limited data from this $\mathrm{AU}$, the minimum number of accumulations was set at 1 , and the maximum at 100 , conservative numbers and significantly lower than the average maximum of the selected analogs. The minimum, mode, and maximum ratios for oil/gas mix were set at $0.1,0.3$, and 0.5 , respectively. These values reflect the measured mix of oil and gas products from the early and middle Eocene source rock strata (Mann and others, 2009) hypothesized to be present in the AU and the proximal position of the AU to sources of terrigenous kerogen throughout the time of deposition. Using this estimate of oil/ gas mix, the minimum, median, and maximum numbers of undiscovered oil accumulations were partitioned among oil and gas accumulations resulting in estimates for the minimum, median, and maximum numbers of accumulations for both oil and gas. Accumulations (all undiscovered) consisting principally of oil (all undiscovered) are calculated as 0,8 , and 50, respectively, at the minimum, median, and maximum. The minimum, median, and maximum numbers of accumulations consisting primarily of gas (all undiscovered) were estimated to be 1,20 , and 90 , respectively. 


\section{Sizes of Undiscovered Oil and Gas Accumulations}

In consideration of the heavy weighting of the analog AUs toward small accumulations in the USGS World Ana$\log$ Database (Charpentier and others, 2008) and because the Lena Prodelta AU is completely unexplored, relatively small accumulation sizes were favored. Accordingly, the minimum oil field size was set at the CARA minimum field size limit of 50 MMBO (Charpentier and Gautier, 2011; Charpentier, 2017, this volume) and the median oil accumulation size was estimated to be $120 \mathrm{MMBO}$ by comparison with the distribution of field sizes reported in the USGS World Analog Database (Charpentier and others, 2008). The maximum oil accumulation size was estimated to be $6,000 \mathrm{MMBO}$ on the basis of the sizes of the largest known accumulations in the analog database and through use of the province geologist's estimate of the largest oil field size expected in the AU, which takes into account the geology of the AU. The latter estimate does not enter directly into the volumetric calculations but acts as a guide to judge the reasonableness of the calculated maximum oil field size at zero probability. Using an energyvolume equivalence factor of 6 , we set the minimum, median, and maximum gas accumulation sizes at 300, 720, and 36,000 $\mathrm{BCFG}$, respectively.

\section{Coproduct Ratios and Ancillary Data}

Coproduct ratios (gas/oil, natural gas liquids (NGL)/gas, liquids/gas) for the Lena Prodelta $\mathrm{AU}$ were estimated from average values reported in Charpentier and others (2008). The median gas/oil ratio for undiscovered accumulations was estimated to be 1,000 cubic feet of gas per barrel of oil (CFG/ $\mathrm{BO}$ ); the median NGL/gas ratio was estimated to be 25 barrels of natural gas liquids per million cubic feet of gas (BNGL/ $\mathrm{MMCFG}$ ); and the median liquids/gas ratio in undiscovered gas accumulations was estimated to be 25 barrels of liquids per million cubic feet of gas (BLIQ/MMCFG). Median API gravity was estimated to be 38 . We estimated drilling depths for undiscovered accumulations from the available seismic data, and water depths within the AU from Jakobsson and others (2004). Drilling depth estimates for undiscovered oil accumulations range from 500 to $4,500 \mathrm{~m}$, with a median of 2,000 $\mathrm{m}$, whereas drilling depth estimates for gas accumulations range from 500 to $7,000 \mathrm{~m}$, with a median of $3,000 \mathrm{~m}$. Estimates of water depths for undiscovered oil and gas fields in the AU range from $100 \mathrm{~m}$ to $3,800 \mathrm{~m}$, with a median of $3,000 \mathrm{~m}$.

\section{Results}

Probabilistic estimates of volumes of undiscovered, technically recoverable hydrocarbons for the Lena Prodelta AU are summarized in table 1 . These results include mean estimates of nearly $1 \mathrm{BBO}$, more than $1.5 \mathrm{TCF}$ gas in oil fields (associated and dissolved gas), about 14 TCF gas in gas fields (nonassociated gas), and $414 \mathrm{MMB}$ of natural gas liquid. The mean largest expected oil field size is calculated to be about $840 \mathrm{MMBO}$ and the mean largest expected nonassociated gas field size is calculated to be about 8 TCF.

\section{Nansen Basin Margin Assessment Unit}

The Nansen Basin Margin AU contains no petroleum exploration wells and very sparse seismic data. This level of exploration places the Eurasian flank of the Nansen Basin into uncertainty category 4 on the scale used by the USGS for the Circum-Arctic Resource Appraisal (Charpentier and Gautier, 2011) (appendix 2).

\section{AU Description}

The Nansen Basin Margin AU consists of the continental slope, rise, and terrace sedimentary prism of the Barents and Kara Seas passive margin of the Eurasia Basin (figs. 1 and 2). This AU corresponds to the "Prograded sedimentary succession across predominately rifted passive margin" unit of Grantz and others $(2010,2011)$ along the Eurasia Basin margin. Grantz and others $(2010,2011)$ defined the updip limit of Cenozoic deposits on the outer part of the Barents-Kara Sea Shelf as the southern limit of this unit and placed the northern boundary of the unit at an inflection in bathymetry that corresponds to the base of the continental rise in the Eurasia Basin. We have accepted these boundaries as the northern and southern limits of the Nansen Basin Margin AU. The eastern boundary of the $\mathrm{AU}$ is at the eastern limit of continental rise, slope, and terrace deposits derived from the Barents-Kara Sea margin of the Eurasia Basin (that is, at the margin of the Lena Prodelta). The western limit of the AU is placed at the limit of significant thicknesses of sediments at the eastern margin of Yermak Plateau. As so defined, the Nansen Basin Margin AU has an areal extent of $291,000 \mathrm{~km}^{2}$. It lies entirely north of the Arctic Circle at water depths that range from less than $100 \mathrm{~m}$ to more than 3,500 $\mathrm{m}$ in the Eurasia Basin.

The Nansen Basin Margin AU consists principally of the Cenozoic clinoform deposits that offlap the continentocean boundary of the southern Eurasia Basin. In the Eurasia Basin, the clinoforms rest on late Paleocene to middle Eocene oceanic crust, whereas south of the continent-ocean boundary they rest on continental crust. The continental crust west of Franz Joseph Land consists of deformed and metamorphosed rocks formed during the Silurian and Devonian Caledonian deformational event covered by a thin sequence of Carboniferous to Cretaceous platform strata. From Franz Joseph Land to the Laptev Sea, the continental crust likely consists of Neoproterozoic metamorphic and igneous rocks and the Ordovician to Permian platformal cover sequence that is characteristic of northern Baltica (Pease and Scott, 2009). A thick sequence of Permian to Cretaceous foreland basin deposits derived from the Uralian and Taimyr orogens forms a depositional trough that rests on these deposits in the area in and around Franz Joseph Land.

The linear arrangements of the Svalbard Franz Joseph Land, and Severnaya Zemlya archipeligos near the edge of the continental margin on the Barents-Kara Sea Shelf suggest that 
they may represent the remnants of the rift shoulder uplift that formed at the time of opening of the Eurasia Basin in the late Paleocene (fig. 2). This interpretation is supported by evidence for cooling at $56 \mathrm{Ma}$ in fission track data collected in Svalbard (Blythe and Kleinspehn, 1998), although these data have been complicated by younger rifting in the Greenland-Norwegian Sea and by the isostatic effect of removal of thick ice sheets in this area in the Pleistocene. If a rift-shoulder uplift is present, it would have significant implications for petroleum exploration in pre-Cenozoic of the Eurasian continental shelf as discussed below.

Seismic-reflection data published by Jokat and Micksch (2004) and Geissler and Jokat (2004) show that the passive continental margin of Nansen Basin is marked by numerous normal faults that drop continental basement down toward Nansen Basin and form local traps for sediment. A particularly large basin in this tectonic location is Sophia Basin near the Yermak Plateau. This basin has a sedimentary thickness of as much as $9 \mathrm{~km}$. On the basis of its large thickness, Geissler and Jokat (2004) suggested that it represents a rift basin that predated opening of the Eurasia Basin. Gravity anomalies identified along the continent-ocean transition suggest the presence of other similar basins.

Jokat and Micksch (2004) divided the seismic stratigraphy along the passive margin of Nansen Basin into four units that have a total maximum thickness of about $4.5 \mathrm{~km}$. The lowest unit (unit IV) is the thickest $(\sim 1,800 \mathrm{~m})$ and probably records deposition during the initial opening phases of the Eurasia Basin in the Paleocene and early Eocene. Unit III is $\sim 900 \mathrm{~m}$ thick and appears to represent deposition in the late Eocene to the time of opening of Fram Strait in the Miocene. Unit II ( 700 m thick) corresponds to Unit NB-2 of Geissler and Jokat (2004), which displays evidence of current activity and is therefore thought to have been deposited following development of a deepwater passage through Fram Strait. Unit $\mathrm{I}$, the highest unit and about $600 \mathrm{~m}$ thick, corresponds to Unit NB-3 and related units of Geissler and Jokat (2004) that are known to be younger than 2.6 Ma from scientific drilling on Yermak Plateau. These deposits consist of glacial-marine sediments characterized by high numbers of dropstones. For the purpose of constructing a burial history model for the Nansen Basin Margin AU, we have modified the stratigraphy of Jokat and Micksch (2004) by subdividing unit IV into units IVa-c and inferring ages for these units from their downlap relations onto magnetic anomalies in underlying oceanic crust (fig. 3).

\section{Geologic Model for Assessment}

The geologic model for the assessment of the Nansen Basin Margin AU is that the dominant petroleum system was derived from early and middle Eocene pelagic deposits that accumulated when the entire Arctic Ocean was a stratified, euxinic basin isolated from the world's oceans. Petroleum having mixed terrigenous and marine kerogen characteristics was generated by burial beneath the thickest part of the passivemargin clinoform section formed from sediments transported across the Barents-Kara continental margin. The reservoirs are hypothesized to be located in slope and submarine-fan sandstones that interfinger with the condensed-facies source rock strata but might also include nonmarine and shallow-marine strata deposited in rift grabens at the time of opening of the Eurasia Basin. Stratigraphic traps in channel and lobe systems, in normal fault and growth fault traps, and in updip truncations on the continental slope are expected to provide the primary sites for petroleum accumulation. Along the continental margin, petroleum accumulations derived from Triassic and Jurassic source rocks of the Barents Sea platform succession that formed prior to opening of the Eurasia Basin might constitute an additional petroleum system in the AU.

\section{Geological Analysis of Assessment Unit Probability}

The probability that the Nansen Basin Margin AU contains at least one undiscovered accumulation equal to or greater than the minimum accumulation size of $50 \mathrm{MMBOE}$ prescribed by the CARA methodology was determined from its geologic and petroleum system characteristics as reviewed below.

Charge.-Other than possible seismic evidence for the presence of gas in the upper part of the section (Geissler and Jokat, 2004), there is no direct evidence of a petroleum system in the Nansen Basin Margin AU. If the depositional model of the Paleogene Arctic Ocean as an isolated stratified, euxenic basin (for example, Brinkhuis and others, 2006) is correct, the early and middle Eocene condensed interval found by scientific drilling on the Lomonosov Ridge probably was deposited in this AU (fig. 7). These source rock strata should be positioned in the lower part of the $4.5-\mathrm{km}$-thick stratigraphic section above oceanic crust near the continent-ocean transition where they would be likely be intercalated with coarser grained deposits shed from the adjacent Eurasia rift margin.

To investigate whether the early and middle Eocene source rocks would be thermally mature if present in the Nansen Basin Margin AU, a one-dimensional thermal history model was constructed at pseudowell NBM located on seismic line 20010100 of Jokat and Micksch (2004, fig. 2) (figs. 1 and 2 ). The pseudowell corresponds to the location of sonobouy 2101 on their seismic profile and is located in the deepest part of Nansen Basin overlying oceanic crust that is here inferred to be late Paleocene. Assuming the age model shown in figure 6 and our model of declining heat flow with time due to cooling of the underlying oceanic crust, the early and middle Eocene interval would have begun to enter the oil window in the Miocene and currently much of the interval is in the oil window $(\mathrm{Ro}=0.85)$ (fig. 11). This suggests that hydrocarbons would have been generated and preserved across much of the deepest, older part of the basin if the early and middle Eocene source rocks are present. Generation earlier than Miocene is possible locally in deep rift basins such as Sophia Basin.

Although data are sparse, the thickness of Cenozoic sedimentary rocks overlying continental crust in the southern 
part of the Nansen Basin Margin AU is less than about 2 $\mathrm{km}$, and thus the Cenozoic stratigraphic section is probably insufficiently thick to have generated hydrocarbons by sedimentary burial of the early and middle Eocene source rocks. Moreover, it seems unlikely that the Eocene source rocks were deposited on the margin of the Barents and Kara Seas because the margin was probably emergent due to Paleocene rift-related uplift. Therefore, charge in this part of the AU would have to have been derived from source rocks in pre-rift strata. Good quality source rocks of Jurassic and Triassic age are known on the Barents shelf and have sourced known petroleum accumulations in the Barents Sea. The Nansen Basin Margin AU, however, lies almost entirely north of the axial part of the rift shoulder uplift. Therefore, the area of the Triassic and Jurassic source rock strata in the AU would be limited to a narrow zone between the continental margin on the north and the tectonic hinge line of the rift shoulder to the south, thus limiting the fetch of the source rocks for generation caused by burial beneath Cenozoic sediments (fig. 7).

If the Triassic and Jurassic source rocks generated hydrocarbons prior to rifting, however, petroleum could have migrated out of depocenters on the Barents Shelf and into prerift basin-margin traps in the AU. Bitumen accumulations are widespread in Franz Joseph Land and are found in Early Cretaceous volcanic units as well as in sedimentary units (for example, Bezrukov, 1997), indicating that long-distance migration in the middle or Late Cretaceous is plausible. This scenario would appear to be limited, however, to the area where the AU transects the Uralian-Taimyr foreland basin deposits near Franz Joseph Land.

On the basis of this analysis, an uncertainty factor of 0.4 was assigned for the charge parameter for the Nansen Basin Margin AU. This level of uncertainty is mildly unfavorable and reflects the uncertain presence of good quality source rocks in the $\mathrm{AU}$, the lack of knowledge about heat flow, and the uncertain possibility for sufficient charge from pre-rift successions on the continental margin to fill traps larger than the minimum size. The hypothetical petroleum system along the Eurasian flank of the Nansen Basin is classified as the Nansen Basin Mesozoic-Cenozoic composite total petroleum system (appendix 2).

Rocks.-Because of the lack of seismic or well data outside of the few seismic lines in Geissler and Jokat (2004), very little is known about reservoir facies and traps in the Nansen Basin Margin AU. Bathymetric data suggest the presence of submarine fans along the base of the continental slope, implying that channel and fan lobe siliciclastic deposits may be the most abundant reservoir types. Seismic data suggest that some of these deposits may be coarse grained (Geissler and Jokat, 2004). These fans probably represent the final site of accumulation of sediments transported northward from extensive source areas in the igneous and metamorphic highlands in Europe during the Cenozoic, particularly during periods of low sea level stand and, therefore, should have good reservoir quality. Numerous slump deposits along the continental margin in the western part of the AU (Geissler and Jokat, 2004) and the irregular bathymetry of the fans elsewhere along the continental slope indicate that slumps are a common feature in the AU. This suggests that slope basins containing ponded sedimentary strata may be a common trapping configuration if they contain pods of reservoir-quality sandstone.

Although displaying evidence of growth-fault systems, shelf-margin facies and other features that could form excellent traps for petroleum, the Cenozoic slope and terrace deposits identified by Geissler and Jokat (2004) seem to be relatively thin $(2-3 \mathrm{~km})$ compared to similar deposits along the continental slopes of Canada, Alaska, and East Siberia in the Amerasia Basin. They also seem to lack large displacement growth faults similar to those observed in these other passive margin sequences (see for example, Grantz and others, 1990; Sekretov, 2001; Houseknecht and others, 2012a). Unlike the deposits of those margins, the Cenozoic deposits of the Barents-Kara Seas margin appear to be dominated by glacial-marine sediments deposited during the Plio-Pleistocene. The origin and thickness of sediment filling the Saint Anna and Voronin Troughs is uncertain but the bathymetric expression of the troughs suggests that they could represent major valleys excavated by ice sheets during Pleistocene lowstands (Kristoffersen, 1990). If correct, these observations may also suggest that much of the upper part of the submarine fans at the base of the Nansen Basin continental slope consists of glacial sediments deposited in the Plio-Pleistocene.

In Franz Joseph Land, the Jurassic and Cretaceous deposits consist of shallow-marine and delta-plain deposits that have a thickness of about $2 \mathrm{~km}$. These strata, composed of sediment derived from the Uralian and Taimyr deformational belts, are overlain and intruded by Cretaceous basalts (Embry, 1994). The reservoir properties of the coarse-grained intervals in these deposits are unknown but appear to be good in Jurassic sandstones in Franz Joseph Land (Bezrukov, 1997). Stratigraphic traps are likely to be present and structural and combination traps caused by extensional faulting and the rift unconformity are also possible. However, the traps and reservoirs may have been degraded by the abundant mafic dikes and sills related to the Early Cretaceous High Arctic Large Igneous Province (HALIP) that intrude the sequence (Embry, 1994).

A third depositional system that could contain good quality reservoir facies and trapping configurations in the Nansen Basin Margin AU are the earliest basin-fill deposits that were deposited in rift grabens such as Sophia Basin during the riftopening phase of the Eurasia Basin. These basins have a high probability of containing coarse clastic material derived from the margins of the basin and nonmarine and shallow-marine depositional environments. High heat flow associated with opening of the Eurasia Basin and subsequent deep burial, however, may have caused diagenetic alteration that was destructive to porosity.

Based on these considerations, a rock probability of 0.7 is assigned to the Nansen Basin Margin AU. This level of uncertainty is moderately favorable based on what is known 


\section{Pseudowell NBM, Nansen Basin Margin AU}
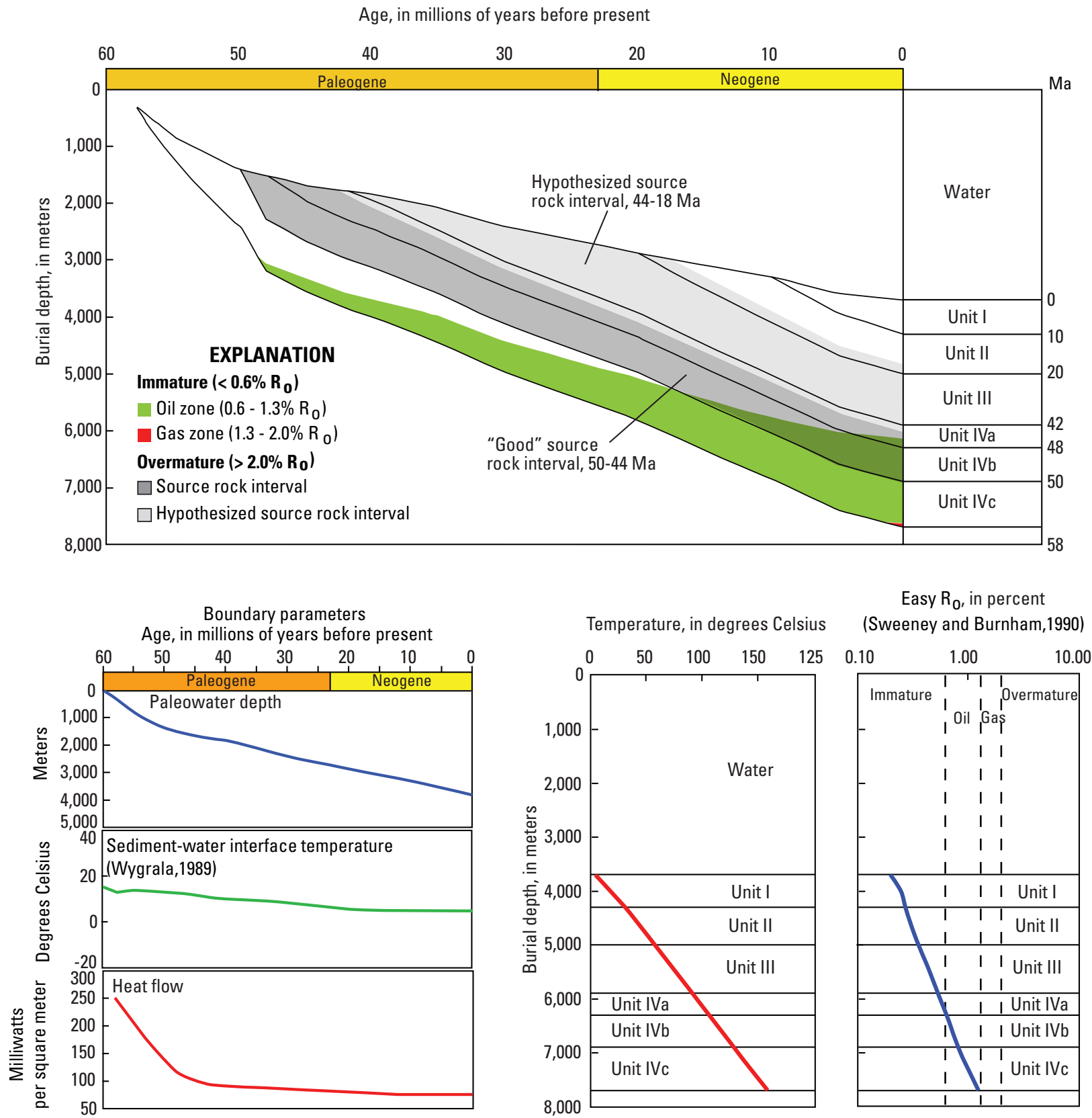

Figure 11. Burial history model for pseudowell NBM in Nansen Basin Margin Assessment Unit (AU) (see fig. 2 for pseudowell location). Stratigraphic section, shown in figure 6, column D, underlain by oceanic crust formed at $~ 58$ Ma. Stratigraphic position of good quality early and middle Eocene source rocks identified in Arctic Coring Expedition (ACEX) core from Lomonsov Ridge shown with dark shading; hypothesized source rocks shown by light shading. Model suggests that early and middle Eocene source rock interval has been in the oil window since the Miocene. 
about other continental margins in the Arctic but reflects the relatively thin sediment cover and lack of data about this continental margin.

Timing and Preservation.-Modeling suggests that hydrocarbon generation in the Paleogene source rocks in deeper parts of the Nansen Basin Margin AU began in the late Paleogene and is occuring today due to continuing subsidence and sedimentary deposition in northern parts of the AU. Potential reservoir facies and stratigraphic traps in Cenozoic deposits developed prior to, or during the time of generation (fig. 11). The reservoir facies lie in close proximity to, and probably interfinger with, the Paleogene source rock strata. Extensional faulting along the margin largely predates deposition, allowing pelagic and hemipelagic facies to provide seals for stratigraphic and structural traps. For these reasons, the timing and preservation are considered to be excellent for charging of these reservoirs.

To the south on the continental margin, charging of preCretaceous reservoirs is complicated by rift-related thermal uplift and formation of a rift shoulder unconformity during formation of the Eurasia Basin in the late Paleocene. This erosion resulted in removal of the Triassic and Jurassic source rocks and Jurassic and Cretaceous reservoir rocks in both the eastern and western parts of the AU, leaving suitable facies remaining only in the Franz Joseph Land-Saint Anna TroughVoronin Trough area. Charging from pre-Cretaceous source rocks would have to have predated the uplift because subsequent burial has been inadequate to cause renewed generation. Any sequestered accumulations, however, probably have been degraded by expansion due to uplift and increased heat flow during rifting in the late Paleocene or were prone to leakage caused by extensional faulting related to the rifting. Thus, the timing and preservation parameter for charging from pre-Cretaceous source rocks seems to be unfavorable.

Based on the favorable conditions for charging of Cenozoic traps from Paleogene source rocks in base-of-slope submarine fan reservoirs, a timing and preservation probability of 0.9 was assigned.

Overall Geologic Probability.-The geologic probability of the presence of an accumulation of minimum size in the Nansen Basin Margin AU, the product of the three geologic and petroleum system probabilities discussed above, is 0.252 (appendix 2). This level of probability suggests that there is a 25 percent chance that the proper conditions to form at least one oil or gas accumulation of minimum size (50 MMBOE recoverable) exists in this AU. This probability, determined from the geology of the $\mathrm{AU}$, was compared to the proabilities of other AUs evaluated by CARA to ensure internal consistency.

The overall probability of 25 percent for the Nansen Basin Margin AU is greater than the 10-percent minimum necessary for a quantitative assessment following CARA methodology (Charpentier and Gautier, 2011; Charpentier, 2017, this volume). Accordingly, an assessment of the sizes and numbers of undiscovered accumulations, the petroleum composition, and other properties for this AU was completed and is discussed below.

\section{Quantitative Assessment of Nansen Basin Margin Assesment Unit}

The assessment of the Nansen Basin Margin AU utilized the analog-based assessment methodology described in Charpentier and Gautier, 2011; Charpentier, 2017, this volume) (appendix 2).

\section{Analogs Used in this Assessment}

Analog assessment units were selected from the USGS World Analog Database (Charpentier and others, 2008) for the purpose of estimating the number and sizes of undiscovered oil and gas accumulations in the Nansen Basin Margin AU. The analog AUs selected for use in this assessment consist of the same suite of analogs employed by Houseknecht and others (2012a) for assessment of the Alaska Passive Margin and Canada Passive Margin AUs of the Amerasia Basin Province. This analog suite includes those AUs having rifted passive margin and passive margin architecture plus those having gravity-induced growth fault trapping systems. Houseknecht and others (2012a) culled the passive margin analog set of AUs containing salt structures, basement-related normal faulting, carbonate reservoirs and other geological parameters not appropriate for the clastic continental margin successions in the Nansen Basin Margin AU. See Houseknecht and others (2012a, table 5) for a list of the analog AUs used in this assessment.

\section{Numbers of Undiscovered Oil and Gas Accumulations}

The number of undiscovered accumulations was estimated from the discovered and undiscovered accumulations in the analog AUs normalized by area (that is, accumulation densities) as determined from the area and geologic characteristics of the Nansen Basin Margin AU. The median of the total accumulations was estimated to be 22 , about half of that estimated for the much thicker Canadian Amerasia Basin passive margin (Houseknecht and others, 2012a). In view of the limited data from the Nansen Basin Margin AU, the minimum number of accumulations was set at 1 . The maximum number of accumulations was set at 75 , about half of the average maximum of the selected analogs, reflecting the lesser duration and thickness of the Eurasia Basin passive margin sequence.

The minimum, median, and maximum ratios for oil/gas mix were set at $0.1,0.4$, and 0.7 , respectively. These values reflect the measured mix of oil and gas products from the early and middle Eocene source rock strata (Mann and others, 2009) and the proximal position of the Nansen Basin Margin AU to sources of terrigenous kerogen on the Barents-Kara Seas Shelf. Using this estimate of oil/gas mix, the minimum, median, and maximum numbers of oil accumulations were partitioned among oil and gas accumulations. The minimum, 
median, and maximum number of accumulations consisting principally of oil (all undiscovered) accordingly are estimated to be 0,8 , and 53 , respectively, whereas the minimum, median, and maximum numbers of accumulations consisting primarily of gas (all undiscovered) are estimated to be 1, 13, and 68 , respectively.

\section{Sizes of Undiscovered Oil and Gas Accumulations}

The minimum size of oil accumulations was set at the minimum accumulation size of $50 \mathrm{MMBOE}$ prescribed for the CARA assessments (Charpentier and Gautier, 2011; Charpentier, 2017, this volume). The maximum and median oil accumulation sizes were estimated to be 2,000 and $100 \mathrm{MMBO}$, respectively, by comparison with the analog set and through consideration of the geologic attributes of the Nansen Basin Margin AU. Using an energy-volume equivalence factor of 6, the minimum, median, and maximum gas accumulation sizes were set at 300,600 , and $12,000 \mathrm{BCFG}$, respectively.

\section{Coproduct Ratios and Ancillary Data}

Coproduct ratios (gas/oil, natural gas liquids (NGL)/gas, liquids/gas) were estimated from global averages from the analog set reported in Charpentier and others (2008). For the Nansen Basin Margin AU, median gas/oil ratio for undiscovered accumulations was estimated to be 1,000 cubic feet of gas per barrel of oil (CFG/BO); median NGL/gas ratio was estimated to be 25 barrels of natural gas liquids per million cubic feet of gas (BNGL/MMCFG); and median liquids/gas ratio in undiscovered gas accumulations was estimated to be 25 barrels of liquids per million cubic feet of gas (BLIQ/MMCFG). Median API gravity was estimated to be 38 . Drilling depths for undiscovered accumulations were estimated from the available seismic data, and water depths within the AU were taken from Jakobsson and others (2004). Drilling depths estimated for both oil and gas accumulations range from 500 to $4,500 \mathrm{~m}$, with a median of 2,000 m. Estimates of water depths range from 100 to $3,500 \mathrm{~m}$, with a median of $2,000 \mathrm{~m}$.

\section{Results}

Probabilistic estimates of volumes of undiscovered, technically recoverable hydrocarbons for the Nansen Basin Margin AU are summarized in table 1. These results include mean estimates of $364 \mathrm{MMBO}$ oil, $568 \mathrm{BCF}$ gas in oil fields (associated and dissolved gas), nearly 3.4 TCF gas in gas fields (nonassociated gas), and $106 \mathrm{MMB}$ natural gas liquids. The mean largest expected oil accumulation is calculated at about $400 \mathrm{MMBO}$ and the mean largest expected gas accumulation is calculated at nearly $3 \mathrm{TCF}$.

\section{Nansen Basin Assessment Unit}

The Nansen Basin AU contains no petroleum exploration wells and seismic data in this basin are extremely sparse. This level of exploration places the Nansen Basin into uncertainty category 4 on the scale used by the USGS for the
Circum-Arctic Resource Appraisal (Charpentier and Gautier, 2011) (appendix 3).

\section{AU Description}

The Nansen Basin AU consists of the Barents Abyssal Plain, which covers the deepest part of the Nansen Basin (fig. 1). Its southern and eastern boundaries are the base of the continental rise along the Barents, Kara, and Laptev Sea continental margins and the northern and western margins are the limits of sedimentary deposits of significant thickness on the southern flank of the Gakkel Ridge. The boundaries of the Nansen Basin AU correspond to those of Grantz and others $(2010,2011)$ for ocean basin sediments in Nansen Basin. The AU lies entirely north of the Arctic Circle and has an aerial extent of $299,000 \mathrm{~km}^{2}$. It rests on oceanic crust at water depths of more than 3,000 $\mathrm{m}$ in most areas and at more than 4,000 m east of Yermak Plateau.

The AU is poorly known because of the lack of wells and seismic data. Jokat and Micksch (2004) reported that the oceanic crust beneath the sedimentary succession of the AU has relief of 1-2 $\mathrm{km}$ because of the presence of many seamounts, but the crust shallows systematically northward toward the Gakkel Ridge (fig. 3). Clinoform reflectors in the basin onlap the oceanic crust from the south, indicating that the basin has largely been filled by hemipelagic sediments and turbidites derived from the Barents-Kara continental margin. However, bathymetry deepens gradually from east to west, suggesting the Lena Prodelta at the eastern end of the basin has acted as a secondary source for sediment transported longitudinally westward through the basin. The largest thicknesses of sedimentary deposits are located along the southern margin of the $\mathrm{AU}$ and totals about $3 \mathrm{~km}$ of sediments (fig. 2).

\section{Geologic Model for Assessment}

The geologic model for the assessment of the Nansen Basin AU hypothesizes that early to middle Eocene condensed-facies source rock strata similar to those recovered by scientific drilling on the Lomonosov Ridge were deposited at or near the base of the sedimentary succession in Nansen Basin. Maturation due to sedimentary burial beneath basin sediments resulted in generation of petroleum, which migrated into nearby stratigraphic traps in intercalated and (or) overlying turbidites shed from the Eurasia continental margin. The potential traps were sealed by pelagic and hemipelagic mudstone units intercalated in the stratigraphic section.

\section{Geological Analysis of Assessment Unit Probability}

The probability that the Nansen Basin AU contains at least one undiscovered accumulation equal to or greater than 
the prescribed minimum accumulation size of $50 \mathrm{MMBOE}$ was determined from its geologic and petroleum system characteristics as reviewed below.

Charge.-There is no direct evidence of a petroleum system in the Nansen Basin AU. If the depositional model of the Paleocene to Miocene Arctic Ocean as an isolated stratified, euxenic basin (for example, Brinkhuis and others, 2006) is correct, the early and middle Eocene condensed interval found by scientific coring on the Lomonosov Ridge should be present in this AU (fig.7). On the basis of its stratigraphic position, the condensed interval probably interfingers with coarser grained deposits that were shed from the Eurasia continental margin. If the condensed facies source rock strata are limited to the early and middle Eocene as recognized on the Lomonosov Ridge, however, the condensed facies would be restricted to the southern part of the AU because the oceanic crust to the north is too young to be overlain by deposits of this age (figs. 3 and 7). If, on the other hand, condensed deposition lasted into the early Miocene as allowed by the late Eocene and early Miocene stratigraphic relations on the Lomonosov Ridge, then condensed facies strata could have been deposited throughout the AU.

To investigate whether the early and middle Eocene source rocks would be thermally mature if present in the Nansen Basin AU, a one-dimensional thermal history model was constructed at pseudowell NB located at sonobouy 2104 near magnetic anomaly $22(\sim 52 \mathrm{Ma})$ on seismic line 20010100 of Jokat and Micksch (2004, their fig. 2) (figs. 2 and 12). We divided the $3 \mathrm{~km}$-thick section into units using a stratigraphic model modified from Jokat and Micksch (2004) (fig. 6, column D). Assuming this model of sedimentation and using our model of declining heat flow with time due to cooling of the underlying oceanic crust, the early and middle Eocene interval would not have been buried deeply enough to enter the oil window (fig. 12). Because this location is near the southern margin of the AU where sediments are the thickest, there is a low probability of generation from the Paleogene source rocks in most parts of this AU.

On the basis of this analysis, an uncertainty factor of 0.3 was assigned for the charge parameter for the AU. This level of uncertainty is moderately unfavorable and reflects the uncertain presence of good quality source rocks in the AU and the likelihood that thermal maturation is insufficient to cause generation, but includes uncertainty about the paleoheat flow in the AU. The hypothetical petroleum system in the Nansen Basin is classified as the Nansen Basin Cenozoic composite total petroleum system (appendix 3).

Rocks.-The clinoform geometry of seismic reflectors suggests that the sedimentary succession in the Nansen Basin contains numerous turbidites derived from the Eurasia continental margin possibly deposited preferentially during times of low stands of sea level. These strata could form good reservoir facies if thick enough and sufficiently coarse-grained. The location of the AU far from the continental margin, however, suggests that the sedimentary section is dominated by distal turbidite facies that probably consist of thin and fine-grained sedimentary units. This would suggest that reservoir facies in the AU have low permeability, although channel and lobe facies associated with major feeder systems might be present locally and provide good reservoir facies. Traps would be dominantly stratigraphic because the section shows little evidence of deformation.

A rock probability of 0.3 is assigned to the Nansen Basin AU. This moderately unfavorable level of uncertainty was assigned because of the thin and fine-grained sedimentation units that are expected to dominate in the AU.

Timing and Preservation.-Turbidites derived from the continental margin were deposited on the condensed source rock strata and may interfinger with the source rocks, suggesting a close proximity that is favorable for charging of the reservoirs (fig. 12). If generation was delayed, however, there is an increasing probability that porosity and permeability might have been diagenetically reduced. There is no evidence of tectonic events that might have caused leakage from traps and reservoirs.

Based on the favorable conditions for charging of Cenozoic traps from Paleogene source rocks in base-of-slope submarine fan reservoirs, a timing and preservation probability of 0.9 is assigned.

Overall Geologic Probability.-The geologic probability of the presence of an accumulation of minimum size in the Nansen Basin AU, the product of the three geologic and petroleum system probabilities discussed above, is 0.081 (appendix $3)$. This level of probability suggests that there is an 8 percent chance that the proper conditions to form at least one oil or gas accumulation of minimum size (50 MMBOE recoverable) exists in this AU. This probability, determined from the geology of the AU, was compared to the probabilities of other AUs within the Circum-Arctic Resource Appraisal to ensure internal consistency within the CARA.

The overall probability of 8 percent for the Nansen Basin Margin AU is less than the 10 percent minimum prescribed for a quantitative assessment (Charpentier and Gautier, 2011; Charpentier, 2017, this volume). Accordingly, an assessment of this $\mathrm{AU}$ was not undertaken.

\section{Amundsen Basin Assessment Unit}

The Amundsen Basin AU contains no petroleum exploration wells and seismic reflection data are limited to a few lines (for example, Jokat and others, 1995; Jokat and Micksch, 2004; Kristoffersen and others, 2004). This level of exploration places the Nansen Basin into uncertainty category 4 on the scale used by the USGS for the Circum-Arctic Resource Appraisal (Charpentier and Gautier, 2011) (appendix 4).

\section{AU Description}

The Amundsen Basin AU encompasses the Pole Abyssal Plain, which extends across the deepest parts of Amundsen Basin (fig. 1). The northern margin of the AU marks the onlap 


\section{Pseudowell NB, Nansen Basin AU}
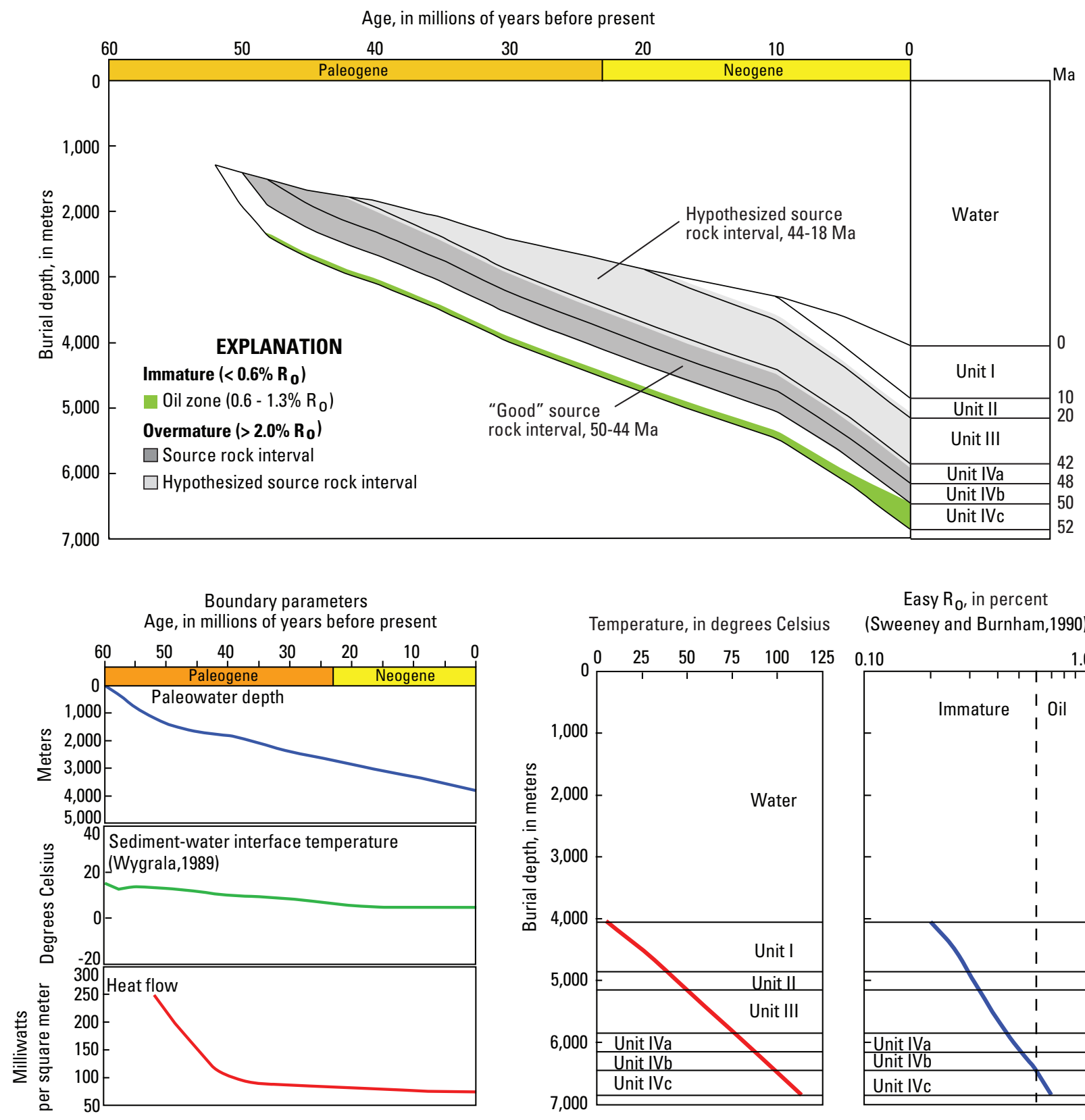

Easy $\mathrm{R}_{0}$, in percent

(Sweeney and Burnham,1990)

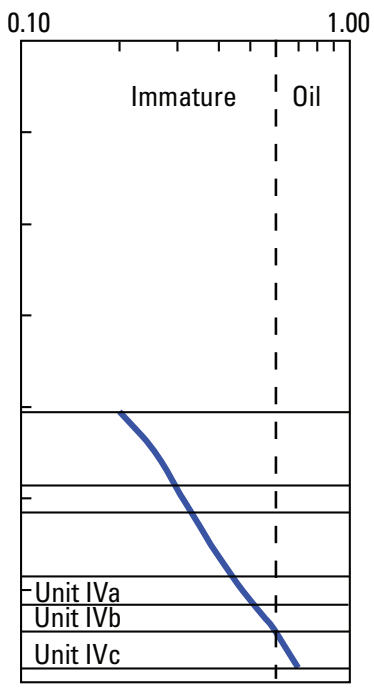

Figure 12. Burial history model for pseudowell NB in Nansen Basin Assessment Unit (AU) (see fig. 2 for pseudowell location). Stratigraphic section, shown in figure 6, column D, is underlain by oceanic crust formed at $\sim 52 \mathrm{Ma}$. Stratigraphic position of good quality early and middle Eocene source rocks identified in Arctic Coring Expedition (ACEX) core on Lomonsov Ridge shown with dark shading; hypothetical source rock interval shown with light shading. Model suggests that all potential source rock intervals are immature. (See fig. 9 caption for modeling details.) 
of Amundsen Basin sediments onto the Lomonosov Ridge and its southern boundary is the limit of sedimentary deposits of measurable thickness on the northern flank of the Gakkel Ridge. The eastern limit of the AU is placed at the foot of the Laptev Prodelta and the western limit at a transform fault inferred by Grantz and others $(2010,2011)$ to bound Eurasia Basin oceanic crust and continental crust beneath Morris Jessup Rise. These boundaries correspond to the extent of ocean basin sediments in Amundsen Basin shown by Grantz and others (2010, 2011). The AU lies entirely north of the Arctic Circle, includes the North Pole, and has an aerial extent of $351,000 \mathrm{~km}^{2}$. It rests on oceanic crust at water depths of more than $4,000 \mathrm{~m}$ except at its far eastern and western limits where water depths are less than $4,000 \mathrm{~m}$.

The sedimentary section in Amundsen Basin rests on oceanic crust that has $0.5-2 \mathrm{~km}$ of relief. The oceanic crust rises southward toward the Gakkel Ridge from its deepest levels of burial about 50 to $100 \mathrm{~km}$ south of the Lomonosov Ridge (Grantz and others, 2010, 2011) (fig. 4). Sedimentary fill has a maximum sediment thickness of $3,200 \mathrm{~m}$ close to the Lomonosov Ridge and thickness declines to less than $500 \mathrm{~m}$ on Gakkel Ridge at the southern edge of the AU (Jokat and others, 1995). The section was divided into eight seismic units by Jokat and others (1995) (fig. 6, column E). The three lowermost units (AB-1 to AB-3) dip away from the Lomonosov Ridge (southward) and are composed of passive-margin sediments derived from the ridge before it subsided below sea level at about $50 \mathrm{Ma}$. Near the Lomonosov Ridge, these units compose more than half the thickness $(\sim 1,700 \mathrm{~m})$ of the Amundsen Basin sedimentary succession. The upper five units record pelagic and turbidity current deposition after the ridge subsided below sea level and significantly lower sedimentation rates prevailed. Sedimentary sources during this time were located in Siberia and Greenland at the eastern and western extremes of the Amundsen Basin AU; therefore, turbidites in this part of the section are thought to be thin and very fine grained.

\section{Geologic Model for Assessment}

The geologic model for the assessment of the Amundsen Basin AU hypothesizes that early to middle Eocene condensed-facies source rock strata similar to those recovered by scientific drilling on the Lomonosov Ridge were deposited at or near the base of the sedimentary succession in Amundsen Basin. Maturation due to sedimentary burial beneath basin sediments resulted in generation of petroleum. The petroleum migrated into nearby stratigraphic traps in underlying coarsegrained sediments derived from the Lomonosov Ridge and was sealed by pelagic and hemipelagic deposits deposited after the ridge subsided below sea level.

\section{Geological Analysis of Assessment Unit Probability}

The probability that the Amundsen Basin AU contains at least one undiscovered accumulation equal to or greater than the prescribed minimum accumulation size of $50 \mathrm{MMBOE}$ was determined from its geologic and petroleum system characteristics as reviewed below.

Charge.-There is no direct evidence of a petroleum system in the Amundsen Basin AU. If the depositional model of the Paleocene to Miocene Arctic Ocean as an isolated stratified, euxenic basin (see Brinkhuis and others, 2006) is correct, it seems likely that the early and middle Eocene ( $\sim 50$ to $44 \mathrm{Ma}$ ) condensed interval found by scientific drilling on the Lomonosov Ridge was deposited in this AU as suggested by Mann and others (2009). The condensed interval probably overlies the coarse-grained deposits derived from the Lomonosov Ridge before the ridge subsided below sea level at about $50 \mathrm{Ma}$. If the condensed facies source rock strata are limited to the early and middle Eocene as recognized on the Lomonosov Ridge, the source rock facies would be restricted to the northern half of the AU because the oceanic crust to the south is too young for deposits of this age (fig. 7). If, on the other hand, condensed deposition lasted into the early Miocene as allowed by the missing 44 to $18 \mathrm{Ma}$ interval in the ACEX cores, then condensed facies strata could have been deposited throughout most of the AU. Migration pathways for charging coarse-grained reservoir facies presumed to lie beneath the condensed strata are probably required for this petroleum system to be effective.

To investigate whether the early and middle Eocene source rocks would be thermally mature if present in the Amundsen Basin AU, a one-dimensional thermal history model was constructed at pseudowell $\mathrm{AB}$ located at sonobouy 9110 near magnetic anomaly 24 ( $\sim 56 \mathrm{Ma})$ on seismic line 91098 of Jokat and others (1995, their figs. 9 and 11) (figs. 2 and 13). We adopted the age model of Jokat and others (1995) for the $2.7-\mathrm{km}$-thick section. Using our model of declining heat flow with time due to cooling of the underlying oceanic crust, the burial history model suggests the early and middle Eocene interval would not have been buried deeply enough to enter the oil window, although Paleocene strata may have become thermally mature shortly after deposition due to high sedimentation rates and high heat flow. Because this location is in the older part of the Amundsen Basin where a relatively thick section is present, there is a low probability of generation from the early and middle Eocene source rocks anywhere else in this AU. Mann and others (2009), in contrast, suggested that the source rock interval would be thermally mature throughout the Amundsen Basin. Their conflicting results stem from their assumptions of constant, high heat flow $\left(\sim 110 \mathrm{mWm}^{-2}\right)$ not provided for in our burial history model. 
On the basis of this analysis, an uncertainty factor of 0.2 was assigned for the charge parameter for the AU. This level of uncertainty is strongly unfavorable and reflects the uncertain presence of good quality source rocks in the AU, the high likelihood that thermal maturation is insufficient to cause generation, and the position of the primary reservoir facies stratigraphically beneath the source rock facies, which would require downward migration for charging. The hypothetical petroleum system in the Amundsen Basin is classified as the Amundsen Basin Cenozoic Composite total petroleum system (appendix 4).

Rocks.-Prior to $50 \mathrm{Ma}$ when the Lomonosov Ridge was emergent, coarse-grained clastic sediments that would make good reservoirs were probably deposited along much of the Lomonosov Ridge where the sedimentary section is thickest. Because these strata were deposited less than $10 \mathrm{Ma}$ after the onset of seafloor spreading, prospective depositional facies may include alluvial and shallow-marine strata as well as turbidite channel and lobe strata accumulated as the newly formed oceani crust subsided and the basin matured. However, the size of drainage systems on the Lomonosov Ridge at this time probably was small because of the limited extent of the ridge, suggesting that the most prospective facies might be those deposited in syntectonic rift basins located close to the Lomonosov Ridge and in early passive margin sediments deposited shortly after opening of the Eurasia Basin when erosive forces were most active on the ridge. Considering the narrowness of the Eurasia Basin in the early Paleogene, it nonetheless remains possible that sedimentary fans shed from the Eurasian margin may have spilled across the young Gakkel Ridge spreading center and into the Amundsen Basin, depositing southerly derived wedges of strata having good reservoir characteristics. The thickening of seismic unit AB-3 ( $\sim 99$ to $46 \mathrm{Ma}$ ) toward Gakkel Ridge reported by Jokat and others (1995) (fig. 4), for example, could be ascribed to sediment derived from the Eurasian margin.

After the submergence of the Lomonosov Ridge at $\sim 50 \mathrm{Ma}$, the Amundsen Basin became largely isolated from sources of coarse-grained sediment that would provide reservoir facies for petroleum accumulations. The provenance of sediments during this period are distant source areas in Greenland and Siberia. The primary reservoirs expected for this interval probably are turbidite channel facies emanating from those source areas during times of low sea level stand. Such systems would be similar to the Plio-Pleistocene turbidite channels described by Kristoffersen and others (2004) in the western part of this AU.

A rock probability of 0.4 is assigned to the Amundsen Basin AU. This level of uncertainty is mildly unfavorable because of the thin and fine-grained sedimentation units that are expected in the AU and the limited extent of favorable facies that were created by erosion of the Lomonosov Ridge prior to its submergence at $\sim 50 \mathrm{Ma}$.

Timing and Preservation.-The presumably coarsegrained rift and passive-margin deposits derived from local sources on the Lomonosov Ridge continental margin that would constitute the best reservoir facies were deposited below the early and middle Eocene condensed source rock strata (figs. 4, 8). The close proximity of these facies, although requiring downward migration, probably is favorable for charging the reservoirs. Migration into local turbidite channel and lobe deposits in Eocene and younger strata would also be favorable. If generation was delayed after deposition, however, there is an increasing probability that porosity and permeability might have been diagenetically reduced. There is little evidence of tectonic events that might have disrupted traps and reservoirs in this AU.

Based on the favorable conditions for charging stratigraphic traps from Paleogene source rocks, a timing and preservation probability of 0.9 is assigned.

Overall Geologic Probability.-The geologic probability of the presence of an accumulation of minimum size in the Amundsen Basin AU, the product of the three geologic and petroleum system probabilities discussed above, is 0.072 (appendix 4). This level of probability suggests that there is a 7 percent chance that the proper conditions to form at least one oil or gas accumulation of the minimum size (50 MMBOE recoverable) exists in this AU. This probability, determined from the geology of the AU, was compared to the probabilities of other AUs to ensure internal consistency within the CircumArctic Resource Appraisal.

The overall probability of 7 percent for the Amundsen Basin Margin AU is less than the 10 percent minimum necessary for a quantitative assessment (Charpentier and Gautier, 2011; Charpentier, 2017, this volume). Accordingly, an assessment of this AU was not undertaken.

\section{Summary of Assessment Results}

The assessment results for the Eurasia Basin Province are listed in table 1. Estimates are provided for the Lena Prodelta and the Nansen Basin Margin AUs; the Nansen Basin and the Amundsen Basin AUs were not quantitatively assessed owing to their low probabilities of containing resources. These estimates represent fully risked, undiscovered, technically recoverable, conventional petroleum resources.

The total risked mean undiscovered oil resource for the Eurasia Basin Province is 1.342 BBO, the total mean undiscovered gas resource is $19.475 \mathrm{TCF}$, and the total mean undiscovered natural gas liquids is $520 \mathrm{MMB}$. These results indicate that the predominant petroleum resource in the province is gas. Expressing the results as oil equivalents (MMBOE), the total mean estimate of undiscovered resource for the province is 5,108 MMBOE. The F50 results of 0 for oil, gas and natural gas liquids in the province has less than a 50-percent chance of containing any petroleum resources at or above the minimum accumulation size of $50 \mathrm{MMBOE}$ (table 1). Despite the low probability of there being petroleum resources above the minimum accumulation size in the province, the F5 results (that is, the best 5 percent chance) indicate that there is a small possibility of large amounts of petroleum resources being present, particularly gas resources (more than 75 TCF). Much of this resource would be expected to occur in the Lena Prodelta AU (55 TCF), if present. 


\section{Pseudowell AB, Amundsen Basin AU}
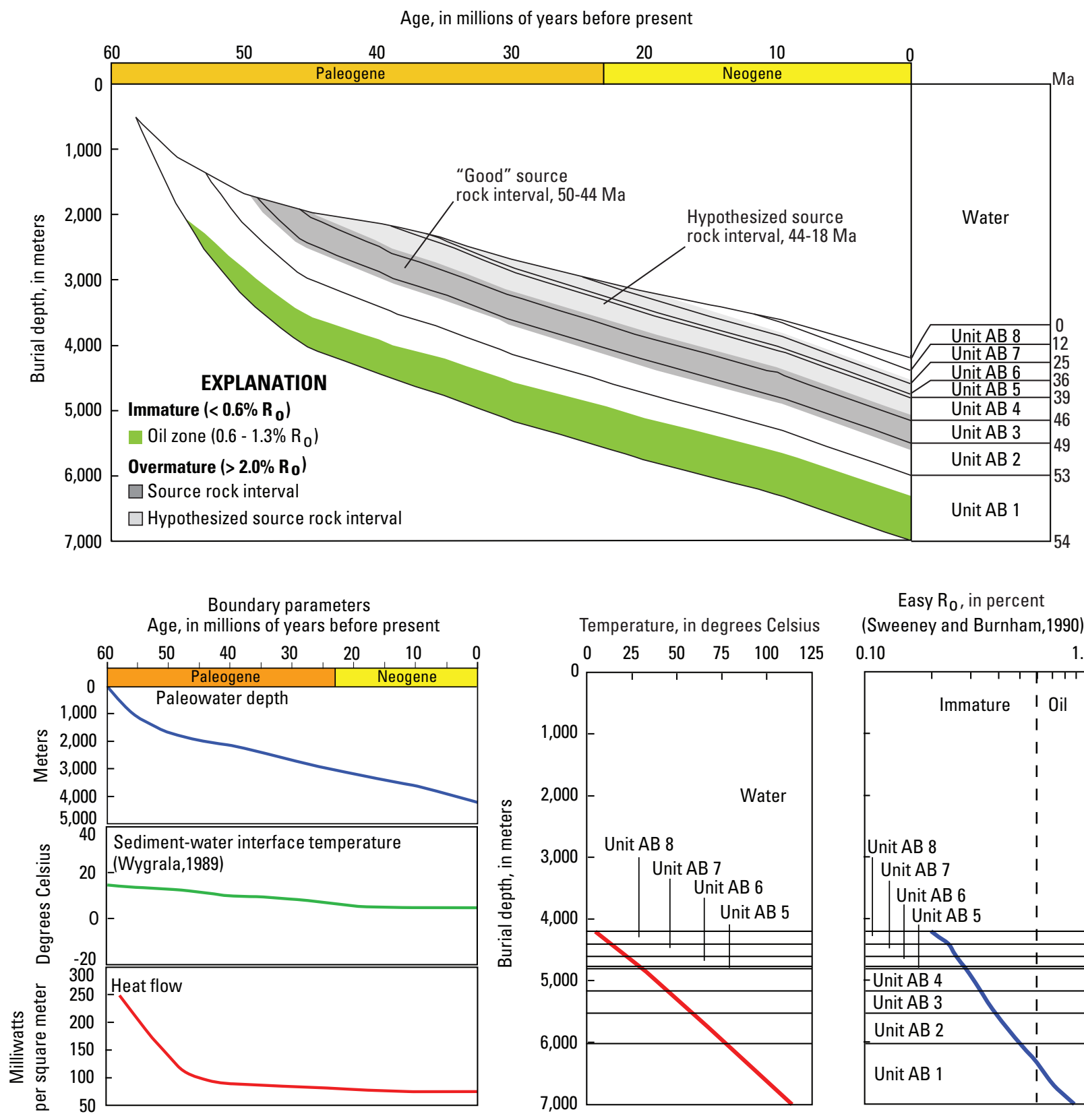

Easy $R_{0}$, in percent (Sweeney and Burnham,1990) 0.10

Figure 13. Burial history model for pseudowell $A B$ in Amundsen Basin Assessment Unit (AU) (see fig. 2 for pseudowell location). Stratigraphic section, shown in figure 6, column E, is underlain by oceanic crust formed at $\sim 54$ Ma. Stratigraphic position of good quality early and middle Eocene source rocks identified in Arctic Coring Expedition (ACEX) core on Lomonsov Ridge shown with dark shading; hypothetical source rock interval shown with light shading. Model shows that source rock interval is immature. 


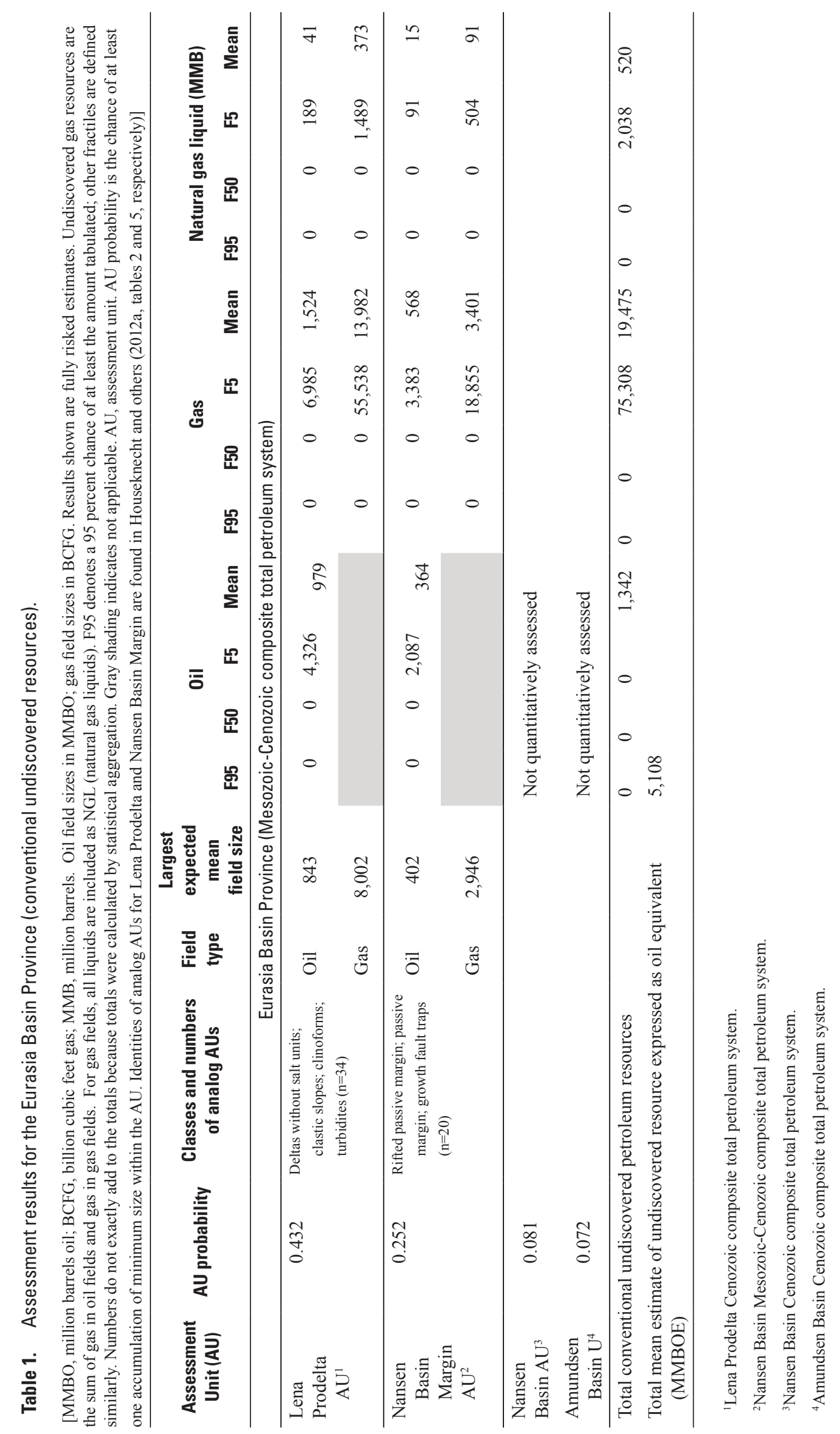




\section{Acknowledgments}

We thank Wilfried Jokat, Sergey Drachev, Ingve Kristoffersen, Arthur Grantz, and Ute Mann, who provided unpublished data and ideas that contributed significantly to this report. We also thank David Houseknecht, Timothy Klett, Kenneth Bird, and Donald Gautier who reviewed the manuscript and offered suggestions that significantly improved the reasoning and clarity of the manuscript.

\section{References Cited}

Backman, J., Jakobsson, M., Frank, M., Sangiorgi, F., Brinkhuis, H., Stickley, C., O’Regan, M., Lovlie, R., Paike, H., Spofforth, D., Gattacecca, J., Moran, K., King, J., and Heil, C., 2008, Age model and core-seismic integration for the Cenozoic Arctic Coring Expedition sediments from the Lomonosov Ridge: Paleoceanography, v. 23, no. 1, PA1S03, doi:10.1029/2007PA001476.

Barrett, P., 2003, Paleoclimatology-cooling a continent: Nature, v. 421, p. 221-223.

Bezrukov, V.M., 1997, Natural bitumens of Graham Bell Island of Franz Josef Land and their significance in assessing oil-gas prospects of the arctic margin of Barents-North Kara shelf: Petroleum Geology, v. 31, no. 4, p. 368-371.

Bird, K.J., Charpentier, R.R., Gautier, D.L., Houseknecht, D.W., Klett, T.R., Pitman, J.K., Moore, T.E., Schenk, C.J., Tennyson, M.E., and Wandry, C.R., 2008, Circum-Arctic Resource Appraisal-Estimates of undiscovered oil and gas north of the Arctic Circle: U.S. Geological Survey Fact Sheet 2008-3049, 4 p.

Bird, K.J., and Houseknecht, D.W., 2011, Geology and petroleum potential of Arctic Alaska, in Spencer, A.M., Embry, A.F., Gautier, D.L., Stoupakova, A.V., and Sørensen, K., eds., Arctic petroleum geology: Geological Society of London Memoir 35, p. 485-499.

Blythe, A.E., and Kleinspehn, K.L., 1998, Tectonically versus climatically driven Cenozoic exhumation of the Eurasian plate margin, Svalbard-Fission track analyses: Tectonics, v. 17 , p. $621-639$.

Brinkhuis, H., and 43 others, 2006, Episodic fresh surface waters in the Eocene Arctic Ocean: Nature, v. 441, p. 606-609, doi:10.1038/nature04692.

Brozena, J.M., Childers, V.A., Lawver, L.A., Gahagan, L.M., Forsberg, R., Faleide, J.I., and Eldholm, O., 2003, New aerogeophysical study of the Eurasia Basin and Lomonosov Ridge-Implications for basin development: Geology, v. 31, p. $825-828$.
Charpentier, R.R., 2017, Methodology for assessment of undiscovered oil and gas resources for the 2008 CircumArctic Resource Appraisal, chap. B of Moore, T.E., and Gautier, D.L., eds., The Circum-Arctic Resource Appraisal: U.S. Geological Survey Professional Paper 1824 [this volume].

Charpentier, R.R., and Gautier, D.L., 2011, U.S. Geological Survey Circum-Arctic Resource Appraisal (CARA) Introduction and summary of organization and methods, in Spencer, A.M., Embry, A.F., Gautier, D.L., Stoupakova, A.V., and Sørensen, K., eds., Arctic petroleum geology: Geological Society of London Memoir 35, p. 145-150.

Charpentier, R.R., Klett, T.R., and Attanasi, E.D., 2008, Database for assessment unit-scale analogs, (exclusive of the United States): U.S. Geological Survey Open-File Report 2007-1404, $61 \mathrm{p}$.

Chen, Z., Osadez, K., Dixon, J., Morrel, G., and Dietrich, J.R., 2007, The future oil discovery potential of the Mackenzie/Beaufort Province [abs.]: American Association of Petroleum Geologists Annual Convention (2007).

Cochran, J.R., Kurras, G.J., Edwards, M.H., and Coakley, J., 2003, The Gakkel Ridge - Bathymetry, gravity anomalies and crustal accretion at extremely slow spreading rates: Journal of Geophysical Research, v. 108, no. B2, p. 2116, doi:10.1029/2002JB001830.

Dai, A., and Trenberth, K.E., 2002, Estimates of freshwater discharge from continents - Latitudinal and seasonal variations: Journal of Hydrometerology, v. 3, p. 660-687.

Dick, H.J., Lin, J., and Schouten, H., 2003, An ultraslowspreading class of ocean ridge: Nature, v. 426, p. 405-412.

Drachev, S.S., Kaul, N., and Beliaev, V.N., 2003, Eurasia spreading basin to Laptev Shelf transition-Structural pattern and heat flow: Geophysical Journal International, v. 152, p. 688-698.

Drachev, S.S., Savostin, L.A., Groshev, B.G., and Bruni, I.E., 1998, Structure and geology of the continental shelf of the Laptev Sea, eastern Russian Arctic: Tectonophysics, v. 298, p. 357-393.

Embry, A.F., 1994, Mesozoic stratigraphy of Franz Josef Land Archipelago, Arctic Russia-A literature review, in Thurston, D.K., and Fujita, K., eds, Proceedings of the first international conference on Arctic margins (1992): U.S. Minerals Management Service OCS Study MMS 94-0040, p. 15-22.

Frakes, L.A., Francis, J.E., and Syktus, J.I., 1992, Climate modes of the Phanerozoic - The history of the Earth's climate over the past 600 million years: Cambridge, Cambridge University Press, $274 \mathrm{p}$.

Franke, D., Hinz, K., and Oncken, O., 2001, The Laptev Sea rift: Marine and Petroleum Geology, v. 18, no. 10, p. 1083-1127. 
Gautier, D.L., Bird, K.J., Charpentier, R.R., Grantz, A., Hourseknecht, D.W., Klett, T.R., Moore, T.E., Pitman, J.K., Schenk, C.J., Schuenemeyer, J.H., Sørensen, K., Tennyson, M.E., Valin, Z.C., and Wandrey, C.J., 2009, Assessment of undiscovered oil and gas in the Arctic: Science, v. 324, p. 1175-1179.

Gautier, D.L., Bird, K.J., Charpentier, R.R., Grantz, A., Houseknecht, D.W., Klett T.R., Moore, T.E., Pitman, J.K., Schenk, C.J., Schuenemeyer, J.H., Sørensen, K., Tennyson, M.E., Valin, Z.C., and Wandrey, C.J., 2011a, Oil and gas resource potential north of the Arctic Circle, in Spencer, A.M., Embry, A.F., Gautier, D.L., Stoupakova, A.V., and Sørensen, K., eds., Arctic petroleum geology: Geological Society of London Memoir 35, p. 151-161.

Gautier, D.L., Stemmerik, L., Christiansen, F.G., Sorensen, K., Bidstrup, T., Bojesen-Koefoed, J.A., Bird, K.J., Charpentier, R.R., Houseknecht, D.W., Klett, T.R., Schenk, C.J., and Tennyson, M.E., 2011b, Assessment of northeast Greenland-Prototype for development of Circum-Arctic Resource Appraisal methodology, in Spencer, A.M., Embry, A.F., Gautier, D.L., Stoupakova, A.V., and Sørensen, K., eds., Arctic petroleum geology: Geological Society of London Memoir 35, p. 663-672.

Gee, D.G., Bogolepova, O.K., and Lorenz, H., 2006, The Timanide, Caledonide and Uralide orogens in the Eurasian high Arctic, and relationships to the palaeo-continents Laurentia, Baltica and Siberia, in Gee, D.G., and Stephenson, R.A., European Lithosphere Dynamics: Geological Society London Memoir, v. 32, p. 507-520.

Geissler, W.H., and Jokat, W., 2004, A geophysical study of the northern Svalbard continental margin: Geophysical Journal International, v. 158, p. 50-66.

Glebovsky, V.Y., Kaminsky, V.D., Minakov, A.N., Merkur'ev, S.A., Childers, V.A., and Brozena, J.M., 2006, Formation of the Eurasia Basin in the Arctic Ocean as inferred from geohistorical analysis of the anomalous magnetic field: Geotectonics, v. 40, p. 263-281.

Golonka, J., and Kiessling, W., 2002, Phanerozoic time scale and definition of time slices, in Kiessling, W., Flügel, E., and Golonka, J., eds., Phanerozoic reef patterns: Society of Economic Paleontologists Special Publication, no. 72, p. 11-20.
Gradstein, F.M., Ogg, J.G., and Smith, A.G., Agterberg, F.P., Bleeker, W., Cooper, R.A., Davydov, V., Gibbard, P., Hinnov, L.A., House, M.R., Lourens, L., Luterbacher, H.P., McArthur, J., Melchin, M.J., Robb, L.J., Shergold, J., Villeneuve, M., Wardlaw, B.R., Ali, J., Brinkhuis, H., Hilgen, F.J., Hooker, J., Howarth, R.J., Knoll, A.H., Laskar, J., Monechi, S., Plumb, K.A., Powell, J., Raffi, I., Röhl, U., Sadler, P., Sanfilippo, A., Schmitz, B., Shackleton, N.J., Shields, G.A., Strauss, H., Van Dam, J., van Kolfschoten, T., Veizer, J., and Wilson, D., 2004, A geologic time scale, 2004: Cambridge, Cambridge University Press, 589 p.

Grantz, A., May, S.C., and Hart, P.E., 1990, Geology of the Arctic continental margin of Alaska, in Grantz, A., Johnson, L., and Sweeney, J.F., eds., The Arctic Ocean region: Geological Society of America, DNAG, The geology of North America, v. L, p. 257-288.

Grantz, A., Pease, V.L., Willard, D.A., Phillips, R.L., and Clark, D.L., 2001, Bedrock cores from $89^{\circ}$ North-Implications for the geologic framework and Neogene paleoceanography of Lomonosov Ridge and a tie to the Barents Shelf: Geological Society of America Bulletin, v. 113, p. 1272-1281.

Grantz, A., Scott, R.A., Drachev, S.S., and Moore, T.E., 2010, Tectonostratigraphic accumulations of the Arctic Region $\left(65^{\circ}-90^{\circ} \mathrm{N}\right)$ that may be prospective for hydrocarbons: American Association of Petroleum Geologists GIS OpenFile, 4 sheets, scale 1:4,000,000, and explanatory pamphlet, 68 p., last accessed October 8, 2015, at http://datapages. com/gis-map-publishing-program/gis-open-files/geographic/ sedimentary-successions-of-the-arctic-region-by-grantz-etal-2010.

Grantz, A., Scott, R.A., Drachev, S.S., Moore, T.E., and Valin, Z.C., 2011, Sedimentary successions of the Arctic region $\left(65^{\circ}-90^{\circ} \mathrm{N}\right)$ that may be prospective for hydrocarbons, in Spencer, A.M., Embry, A.F., Gautier, D.L., Stoupakova, A.V., and Sørensen, K., eds., Arctic petroleum geology: Geological Society of London Memoir 35, p. 17-37.

Hardenbol, J., Thierry, J., Farley, M.B., Jacquin, T., de Graciansky, P.C., and Vail, P.R., 1998, Mesozoic and Cenozoic sequence chronostratigraphic framework for European basins, in de Graciansky, P.C., Hardenbol, J., Jacquin, T., and Vail, P.R., eds., Mesozoic and Cenozoic sequence stratigraphy of European basins: Society for Sedimentary Geology Special Publication, no. 60, p. 3-13. 
Henry, M.E., Ahlbrandt, T.S., Charpentier, R.R., Gautier, D.L., Klett, T.R., Pollastro, R.M., Schenk, C.J., and Ulmishek, G.F., 2006, Assessment of undiscovered oil and gas resources of the Mackenzie Delta Province, North America, 2004: U.S. Geological Survey Fact Sheet 2006-3002, 2 p. (Also available at http://pubs.usgs.gov/fs/2006/3002/pdf/ FS-2006-3002.pdf.)

Houseknecht, D.W., and Bird, K.J., 2011, Geology and petroleum potential of the rifted margins of the Canada Basin, in Spencer, A.M., Embry, A.F., Gautier, D.L., Stoupakova, A.V., and Sørensen, K., eds., Arctic petroleum geology: Geological Society of London Memoir 35, p. 509-526.

Houseknecht, D.W., Bird, K.J., and Garrity, C.P., 2012a, Assessment of undiscovered petroleum resources of the Amerasia Basin Petroleum Province: U.S. Geological Survey Scientific Investigations Report 2012-5146, 35p.

Houseknecht, D.W., Bird, K.J., and Garrity, C.P., 2012b, Assessment of undiscovered petroleum resources of the Arctic Alaska Petroleum Province: U.S. Geological Survey Scientific Investigations Report 2012-5147, 26 p.

Houseknecht, D.W., Burns, W.M., and Bird, K.J., 2012c, Thermal maturation history of Arctic Alaska and the southern Canada basin, in Harris, N.B., and Peters, K.E., eds., Thermal analysis of sedimentary basins - methods and case studies: SEPM (Society for Sedimentary Geology) Special Publication 103, p. 199-219.

Jakobsson, M., Backman, J., Rudels, B., Nycander, J., Frank, M., Mayer, L., Jokat, W., Sangiorgi, F., O’Regan, M., Brinkhuis, H., King, J., and Moran, K., 2007, The early Miocene onset of a ventilated circulation regime in the Arctic Ocean: Nature, v. 447, p. 986-990.

Jakobsson, M., Macnab, R., Cherkis, N., and Schenke, H., 2004, International bathymetric chart of the Arctic Ocean (IBCAO): National Geophysical Data Center, Research Publication RP-2, 1 plate, scale 1:6,000,000.

Jokat, W., 2005, The sedimentary structure of the Lomonosov Ridge between $88^{\circ} \mathrm{N}$ and $80^{\circ} \mathrm{N}$ : Geophysical Journal International v. 163 , p. 698-726.

Jokat, W., Ritzmann, O., Schmidt-Aursch, M.C., Drachev, S., Gauger, S., and Snow, J., 2003, Geophysical evidence for reduced melt production on the Arctic ultraslow Gakkel mid-ocean ridge: Nature, v. 423, p. 962-965.

Jokat, W., and Micksch, U., 2004, Sedimentary structure of the Nansen and Amundsen basins, Arctic Ocean: Geophysical Research Letters, v. 31, no. 2, doi:10.1029/2003GL018352, 4 p.

Jokat, W., Weigelt, E., Kristoffersen, Y., Rasmussen, T., and Schöne, T., 1995, New insights into the evolution of the Lomonosov Ridge and the Eurasian Basin: Geophysical Journal International, v. 122, p. 378-392.
Klett, T.R., and Pitman, J.K., 2011, Geology and petroleum potential of the East Barents Sea basins and Admiralty arch, in Spencer, A.M., Embry, A.F., Gautier, D.L., Stoupakova, A.V., and Sørensen, K., eds., Arctic petroleum geology: Geological Society of London Memoir 35, p. 295-310.

Klett, T.R., Wandrey, C.J., and Pitman, J.K., 2011, Geology and petroleum potential of the north and east margins of the Siberian craton, in Spencer, A.M., Embry, A.F., Gautier, D.L., Stoupakova, A.V., and Sørensen, K., eds., Arctic petroleum geology: Geological Society of London Memoir 35 , p. 413-431.

Klubov, B.A., Rogozina, Y.A., and Shkatov, Y.P., 2000, Geochemical indexes of oil-gas occurrence in offshore areas of Franz Josef Land: Petroleum Geology, v. 34, p. 329-334.

Kristoffersen, Y., 1990, Eurasia Basin, in Grantz, A., Johnson, L., and Sweeney, J.F., eds., The Arctic Ocean region: Geological Society of America, DNAG, The Geology of North America, v. L, p. 365-378.

Kristoffersen, Y., 2000, The Eurasia Basin-An update from a decade of geoscientific research: Polarforschung, v. 68, p. 11-18.

Kristoffersen, Y., Sorokin, M.Y., Jokat, W., and Svendsen, O., 2004, A submarine fan in the Amundsen Basin, Arctic Ocean: Marine Geology, v. 204, p. 317-324.

Mann, U., Knies, J., Chand, S., Jokat, W., Stein, R., and Zweigel, J., 2009, Evaluation and modeling of Tertiary source rocks in the central Arctic Ocean: Marine and Petroleum Geology, v. 26, p. 1624-1639.

Miller, K.G., Kominz, M.A., Browning, J.V., Wright, J.D., Mountain, G.S., Katz, M.E., Sugarman, P.J., Cramer, B.S., Christie-Blick, N., and Pekar, S.F., 2005, The Phanerozoic record of global sea-level change: Science, v. 310, p. 1293-1298, doi:10.1126/science.1116412.

McKenzie, D.P., 1967, Some remarks on heat flow and gravity anomalies: Journal of Geophysical Research, v. 72, p. 6261-6273.

Michael, P.J., Langmuir, C.H., Dick, H.J.B., Snow, J.E., Goldstein, S.L., Graham, D.W., Lehnert, K., Kurras, G., Jokat, W., Mühe, R., and Edmonds, H.N., 2003, Magmatic and amagmatic seafloor generation at the ultraslow-spreading Gakkel Ridge, Arctic Ocean: Nature v. 423, p. 956-961.

Moore, T.E., Grantz, A. Pitman, J.K., and Brown, P.J., 2011, A first look at the petroleum geology of the Lomonosov Ridge microcontinent, Arctic Ocean, in Spencer, A.M., Embry, A.F., Gautier, D.L., Stoupakova, A.V., and Sørensen, K., eds., Arctic petroleum geology: Geological Society of London Memoir 35, p. 751-769.

Moore, T.E., and Pitman, J.K., 2011, Geology and petroleum potential of the Eurasia Basin, in Spencer, A.M., Embry, A.F., Gautier, D.L., Stoupakova, A.V., and Sørensen, K., eds., Arctic petroleum geology: Geological Society of London Memoir 35, p. 731-750. 
Moran, K., and 36 others, 2006, The Cenozoic palaeoenvironment of the Arctic Ocean: Nature, v. 441, p. 601-605.

O’Leary, N., White, N., Tull, S., Bashilov, V., Kuprin, V., Natapov, L., and Macdonald, D., 2004, Evolution of the Timan-Pechora and South Barents Sea basins: Geological Magazine, v. 141, p. 141-160.

O’Regan, M., Moran, K., Backman, J., Jakobsson, M., Sangiorgi, F., Brinkhuis, H., Pockalny, R., Skelton, A., Stickley, C., Koc, N., Brumsack, H., and Willard, D., 2008, MidCenozoic tectonic and paleoenvironmental setting of the central Arctic Ocean: Paleoceanography, v. 23, PA1S20, doi:1029/2007PA001559, 15 p.

Pease, V., and Scott, R.A., 2009, Crustal affinities in the Arctic Uralides, northern Russia-Significance of detrital zircon ages from Meoproterozoic and Palaeozoic sediments in Novaya Zemlya and Taimyr: Journal of Geological Society, London, v. 166, p. 517-527.

Schenk, C.J., 2011a, Geology and petroleum potential of the Timan-Pechora Basin province, Russia, in Spencer, A.M., Embry, A.F., Gautier, D.L., Stoupakova, A.V., and Sørensen, K., eds., Arctic petroleum geology: Geological Society of London Memoir 35, p. 283-294.

Schenk, C.J., 2011b, Geology and petroleum potential of the West Greenland-East Canada province, in Spencer, A.M., Embry, A.F., Gautier, D.L., Stoupakova, A.V., and Sørensen, K., eds., Arctic petroleum geology: Geological Society of London Memoir 35, p. 627-645.

Sekretov, S.B., 2001, Northwestern margin of the East Siberian Sea, Russian Arctic-Seismic stratigraphy, structure of the sedimentary cover and some remarks on the tectonic history: Tectonophysics, v. 339, p. 353-383.

Sekretov, S.B., 2002, Structure and tectonic evolution of the southern Eurasia Basin, Arctic Ocean: Tectonophysics, v. 351, p. 193-243.
Sørensen, K., Gautier, D., Pitman, J., Jackson, H.R., and DahlJensen, T., 2011, Geology and petroleum potential of the Lincoln Sea Basin, offshore North Greenland, in Spencer, A.M., Embry, A.F., Gautier, D.L., Stoupakova, A.V., and Sørensen, K., eds., Arctic petroleum geology: Geological Society of London Memoir 35, p. 673-684.

Stein, R., 2007, Upper Cretaceous/Lower Tertiary black shales near the North Pole-Organic-carbon origin and source rock potential: Marine and Petroleum Geology, v. 24, p. 67-73.

Stein, R., Boucsein, B., and Meyer, H., 2006, Anoxia and high primary production in the Paleogene central Arctic Ocean-First detailed records from Lomonosov Ridge: Geophysical Research Letters, v. 33, L18606, doi:10.1029/2006GL026776, 6 p.

Stein, R., Brass, G., Graham, D., Pimmel, A., and the Shipboard Scientific Party, 1995, Hydrocarbon measurements at the Arctic Gateways Sites, ODP Leg 151, in Myhre, A.M., Thiede, J., and Firth, J., eds., Proceedings of the Ocean Drilling Program, Initial Reports: College Station, Texas, Ocean Drilling Program, v. 151, p. 385-395.

Sweeney, J.J., and Burnham, A.K., 1990, Evaluation of a simple model of vitrinite reflectance based on chemical kinetics: American Association of Petroleum Geologists Bulletin, v. 74, p. 1559-1570.

Ulmishek, G.F., and Klemme, H.D., 1990, Depositional controls, distribution, and effectiveness of world's petroleum source rocks: U.S. Geological Survey Bulletin B-1931, 59 p.

Vogt, P., Taylor, P.T., Kovacs, L.C., and Johnson, G.L., 1979, Detailed aeromagnetic investigation of the Arctic Basin: Journal Geophysical Research, v. 84, p. 1071-1089.

Wei, M., and Sandwell, D., 2006, Estimates of heat flow from Cenozoic seafloor using global depth and age data: Tectonophysics, v. 417, p. 325-335.

Wygrala, B.P., 1989, Integrated study of an oil field in the southern Po Basin, northern Italy: Berichte der Kemforschungsanlage Julich, no. 23113, 217 p. 


\section{Appendixes}

Appendixes are available only online, and may be accessed at https://doi.org/10.3133/pp1824DD

Appendix 1. Input data for the Lena Prodelta Assessment Unit

Appendix 2. Input data for the Nansen Basin Margin Assessment Unit

Appendix 3. Input data for the Nansen Basin Assessment Unit

Appendix 4. Input data for the Amundsen Basin Assessment Unit 


\section{总}

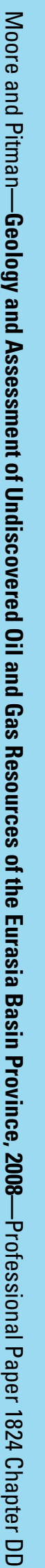

